\section{5}

$S$

14.GS:

CIR 326

C. 2 .
STATE OF ILLINOIS

DEPARTMENT OF REGISTRATION AND EDUCATION
SPECHTS FERRY (MIDDLE ORDOVICIAN) BRYOZOAN FAUNA FROM ILLINOIS, WISCONSIN, AND IOWA

ILLINOIS GEOLOGICAC

T. G. Perry

ILLINOIS STATE GEOLOGICAL SURVEY URBANA 


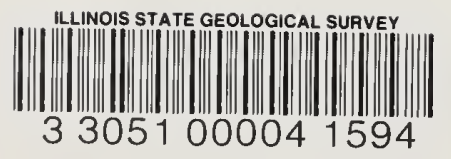




\title{
SPECHTS FERRY (MIDDLE ORDOVICIAN) BRYOZOAN FAUNA FROM ILLINOIS, WISCONSIN, AND IOWA
}

\author{
T. G. Perry
}

\begin{abstract}
The Spechts Ferry bryozoan fauna from ten localities in northwestern Illinois, southwestern Wisconsin, and southea stern Iowa includes the trepostomatous genera Homotry paUlrich, Prasopora Nicholson \& Etheridge, Heterotrypa Nicholson, Dekayella Ulrich, Monotrypella Ulrich, Batostoma Ulrich, and Diplotrypa Nicholson and the cryptostomatous genus Stictoporella Ulrich. Cyclostomatous bryozoans were not found. Twelve species are described and illustrated, five of which have been recognized previously in other areas. The genera Homotrypa and Stictoporella dominate the fauna. The genus Rhinidictya Ulrich (a junior synonym of Stictopora Hall), commonly found in strata of Trentonian age in Minnesota, is represented sparingly in the Spechts Ferry fauna by fragmentary, poorly preserved specimens that cannot be assigned to previously described species. The genus Hallopora Bassler is not recognized in the Spechts Ferry fauna, although it is encountered commonly in Middle Ordovician rocks in Minnesota and elsewhere. The Spechts Ferry Shale cannot be assigned to either Blackriveran or Trentonian on the basis of its bryozoan fauna because its widely distributed species span the boundary.
\end{abstract}

\section{INTRODUCTION}

The Spechts Ferry Shale is a distinctive unit in the Champlainian (Middle Ordovician) strata of the upper Mississippi Valley. It was originally the undifferentiated basal part of the Decorah Shale, and was correlated with Trentonian strata, but later it was for many years included in the underlying Platteville Limestone of Blackriveran age. More recently it has been returned to the Decorah Shale and assigned to the Trentonian. As bryozoans are commonly abundant and well preserved in the Spechts Ferry Shale, it was hoped that their study would contribute toward determining the age of the shale. 
The purpose of this report is to describe the bryozoan fauna collected from ten exposures in northwestern Illinois, southwestern Wisconsin, and northeastern Iowa. Discussion of the physical stratigraphy of the Spechts Ferry and detailed consideration of changes in its stratigraphic placement within the Middle Ordovician lie outside the scope of this report. The more significant papers dealing with the stratigraphic aspects of the Spechts Ferry are by Kay (1929, p. 639-671; 1931 , p. 361-376; 1934, p. 328-331; 1935, p. 281-295; 1940, p. 235), Kay and Atwater (1935, p. 98-111), Bays and Raasch (1935, p. 296-301), Templeton and Willman (1952), and Agnew et al. (1956, p. 286-289).

\section{Lithology of Spechts Ferry Shale}

In the collecting area of this report, dark green, medium gray, and greengray thin-bedded soft shale is the dominant lithology in the Spechts Ferry Shale. Locally the shale is pyritic. Some Spechts Ferry exposures have a massive or blocky appearance as the bedding is not readily discernible. Bryozoans and other fossils generally are moderately abundant in the shale, particularly if it is somewhat calcareous or includes thin beds of highly argillaceous limestone. In contrast, shale in some excellent Spechts Ferry exposures, such as one located high in a ravine in the $S W \frac{1}{4}$ NW $\frac{1}{4}$ sec. 10, T. 2 N., R. 3 W., near Potosi Station, Grant County, Wisconsin, virtually lacks bryozoans and other fossils.

Light to medium gray, fine- to medium-grained argillaceous limestone is common in the Spechts Ferry, usually in beds less than 6 inches thick. Fresh surfaces of such limestone beds commonly have a green tint and commonly show discontinuous lenses of soft, dark gray shale that generally are less than 0.5 inch thick and 2 or 3 feet long. Fossils, particularly bryozoans and brachiopods, generally abound on the upper surfaces of limestone beds and in shale immediately above the limestone strata.

\section{Material Studied}

Bryozoans on which this report is based have been collected from the following localities:

1. Abandoned quarry and ravine, $\mathrm{SE}_{\frac{1}{4}} \mathrm{NW} \frac{1}{4} \mathrm{sec} .4, \mathrm{~T} .90 \mathrm{~N},, \mathrm{R} .2 \mathrm{E}$., near Spechts Ferry Station, Dubuque County, Iowa.

2. Abandoned quarry, SW $\frac{1}{4} \mathrm{NW} \frac{1}{4} \mathrm{sec} .3, \mathrm{~T} .90$ N., R. 2 E., approximately 1.2 miles southeast of Spechts Ferry Station and about 200 feet south of the C. M. and St. P. rail line, in Dubuque County, Iowa.

3. Roadcut, SW $\frac{1}{4}$ sec. 5, T. 92 N., R. 2 W., on U. S. Hwy. 52, approximately 1 mile north of Guttenberg, Clayton County, Iowa.

4. Roadcut, NW $\frac{1}{4}$ SE $\frac{1}{4}$ sec. 11, T. 2 N., R. 2 W., 0.25 mile south of the intersection of U. S. Hwy. 151 and Blockhouse Creek, Grant County, Wisconsin.

5. Roadcut, SE $\frac{1}{4}$ NW $\frac{1}{4}$ sec. 7, T. 2 N., R. 2 W., on U. S. Hwy. 61, Grant County, Wisconsin.

6. Abandoned quarry, approximately 400 feet north of Wis. Hwy. 35, 3.1 miles east of the junction of Wis. Hwy. 35 and County Hwy. U, Grant County, Wisconsin.

7. Abandoned quarry, north roadside of Wis. Hwy. 35, 2.6 miles east of junction of Wis. Hwy. 35 and County Hwy. U, Grant County, Wisconsin. 
8. Roadcut, County Hwy. U, 3.05 miles north of the junction of County Hwy. U and Wis. Hwy. 133, Grant County, Wisconsin.

9. Natural exposure, SE $\frac{1}{4} \mathrm{SE} \frac{1}{4} \mathrm{NW} \frac{1}{4} \mathrm{sec} .34, \mathrm{~T} .29 \mathrm{~N}$., R. 1 E., on right bank of Galena River, approximately 4.0 miles north of Galena, Illinois.

10. Natural exposure, NE $\frac{1}{4}$ SE $\frac{1}{4}$ SW $\frac{1}{4}$ sec. 34, T. 29 N., R. 1 E., about 50 feet north of abandoned railroad bed, approximately 3.7 miles north of Galena, Illinois.

The stratigraphic position of the specimens within the Spechts Ferry, which is invariably less than 10 feet thick in the collecting area, was not recorded. Many of the weathered-out specimens obviously were somewhat out of place but still resting on Spechts Ferry strata. However, all specimens described and studied for this project came without question from the Spechts Ferry.

Tangential and longitudinal sections of 245 specimens, representing somewhat over half of the specimens amenable to sectioning in the collection, were prepared by the author during the course of this study. Several sections were made from some of the zoaria. All sections and remnants of the zoaria from which they were prepared, as well as all nonsectioned specimens, have been deposited in the paleontologic collections of the Illinois State Geological Survey, Urbana, Illinois.

\section{Age and Distribution of Spechts Ferry Bryozoans}

Although originally defined as the basal member of the Decorah Shale (Kay, 1928 , p. 16), the Spechts Ferry Shale later was made the uppermost member of the Platteville Formation (Kay, 1935, p. 287-289), and was generally considered to be equivalent to Black River strata in New York. Herbert (1949) returned the Spechts Ferry to the Decorah on the basis of lithologic evidence and the presence of a widespread unconformity at the base of the Spechts Ferry. Templeton and Willman (1952) correlated the Spechts Ferry with the Selby Shale, the basal member of the Rockland Formation, at the base of the Trenton Group in the New York type region. The Spechts Ferry was assigned to the Trentonian Stage on the Ordovician correlation chart (Twenhofel et al., 1954). Agnew et al. (1956, p. 286-289) also returned the Spechts Ferry to the Decorah Shale.

The age of the Spechts Ferry cannot be established definitely as either Blackriveran or Trentonian on the basis of its bryozoan fauna. The use of bryozoans for making regional correlations and age determinations is hampered greatly by lack of knowledge concerning bryozoan faunas of Middle Ordovician age. Only three faunas of this age from widely separated regions in North America have been described with any degree of completeness (Coryell, 1921; Loeblich, 1942; Fritz, 1957), notwithstanding that many formations of Middle Ordovician age have rich and diversified bryozoan faunas (Bassler, 1933, p. 282). Unfortunately, the bryozoan faunas of the type sections of the Black River and Trenton Groups are virtually unknown. Much of our knowledge concerning the geographic and stratigraphic distribution of Middle Ordovician bryozoan species is based on faunal lists included in papers that are primarily stratigraphic in nature, as in Bassler (1932, p. 59-115) and Wilson (1949, p. 24-170). Such lists are not entirely satisfactory for use in correlation studies because the relative abundances of the species are not usually stated nor are they figured or described so that identifications may be verified. For these reasons, namely, the small number of adequately described faunas of Middle Ordovician age and faunas known very incompletely through faunal lists, bryozoans presently are not as practical for correlation studies and age determination as are better known groups of invertebrate fossils. 
Potentially, however, bryozoans should have great value in stratigraphic studies because of their common occurrence and because they can be readily identified from fragmentary specimens.

If, however, bryozoans are particularly susceptible to facies changes, as has been stated by Troedsson (1928, p. 183) and mildly insinuated by Horowitz and Perry (1956, p. 1707), this circumstance would detract from their effectiveness in regional correlation studies. Bassler's investigation (1911) of the early Paleozoic Bryozoa of the Baltic region indicated the cosmopolitan distribution of many bryozoan species. For example, Bassler (1911, p. 32) stated that 23 of the 58 species of the Rhinidictya bed in the Decorah Shale of the Minnesota section are found in Ordovician strata of the Baltic region; this and other faunal comparisons given by Bassler do not suggest rigorous facies control of Paleozoic bryozoan faunas. As will be shown in the following discussion, five of the twelve species recognized in the Spechts Ferry have a considerable geographic range, which again suggests that facies changes do not exercise greater control on the distribution of bryozoans than on many other kinds of invertebrate fossils.

Five of the 12 species in the Spechts Ferry have been described by Ulrich (1895, p. 96-332) from rocks of Middle Ordovician age in Minnesota where they are found mainly in the "Lower Third" (containing basal Stictoporella bed) and "Middle Third" (Rhinidictya and Ctenodonta beds) Trenton Shales of Ulrich's stratigraphic classification. These strata are now assigned to the Decorah Shale (Kay, 1929 , p. 642, table 1). Species common to the Spechts Ferry and the Decorah of Minnesota are: Batostoma winchelli (Ulrich), B. winchelli spinulosum Ulrich, Dekayella praenuntia echinata Ulrich, Homotrypa exilis Ulrich, and Stictoporella frondifera Ulrich. The Spechts Ferry fauna also includes Prasopora simulatrix orientalis Ulrich, a form recognized (Ulrich, 1895, p. 246-248) from rocks of Trenton age near Ottawa and Peterborough in southern Ontario and from strata of the same age at Trenton Falls, New York. Stictoporella frondifera, a very abundant species in the Spechts Ferry, allegedly is restricted to the Stictoporella beds of the Minnesota section (Ulrich, 1895, p. 184; Bassler, 1911, p. 28) in which it is found abundantly. The genus Hallopora Bassler presumably is a conspicuous faunal element in the Middle Ordovician bryozoan fauna of Minnesota, as Ulrich (1895, p. 277-285) recognized nine species and one variety of this genus. Hallopora, a very common Ordovician genus, was not found in the Spechts Ferry in the area under study. The genus Stictopora Hall, apparently a commonly encountered form in the Decorah strata of Minnesota (Ulrich, 1895, p. 124-138), is represented sparingly in the Spechts Ferry by fragmentary unidentifiable specimens.

Fritz (1957) described the bryozoan fauna of the Ottawa Formation, which includes strata of Blackriveran and Trentonian ages. Four of the twelve species in the Spechts Ferry are known also from the Ottawa Formation, including Batostoma winchelli, B.winchelli spinulosum, Dekayella praenuntia echinata, and Prasopora simulatrix orientalis. In addition, Fritz (1957, p. 22, 23) recorded a single specimen that is compared to Homotrypa minnesotensis Ulrich; her illustrations and description indicate that the specimen is allied very closely to Homotrypa exilis, a species found abundantly in the Spechts Ferry. The stratigraphic distribution of these forms as given by Fritz (1957, table 2) was not highly suggestive of either Blackriveran or Trentonian age, as two species, $B$. winchelli and $P$. simulatrix orientalis, are found in Black River and Trenton equivalents in the Ottawa Formation, although the latter is more abundant in rocks of Trentonian age. 
$D$. praenuntia echinata is abundant in the Trenton equivalents in the formation but not noted from the Black River, and B. winchelli spinulosum was found by Fritz only in Trentonian beds in the formation. In view of their stratigraphic distribution in the Ottawa Formation, these four species considered collectively may possibly be somewhat more indicative of Trentonian age than of Blackriveran age. The most striking difference between the bryozoan faunas of the Spechts Ferry and the Ottawa Formation is the great abundance of Stictoporella Ulrich in the Spechts Ferry and its apparent absence in the Ottawa fauna.

Loeblich (1942, p. 417-435) recognized two species, Dekayella praenuntia echinata and Batostoma winchelli, in the Bromide Formation of Oklahoma that are found also in the Spechts Ferry. Loeblich recorded these species from the upper 25 feet of the formation in strata that generally are considered to be Blackriveran in age.

Some Spechts Ferry species appear in faunal lists of formations of Middle Ordovician age. Admittedly, more references in which these species are listed could be included here. Prasopora simulatrix orientalis, a comparatively rare species in the Spechts Ferry, presumably is more indicative of Trentonian age, although Coryell $(1916$, p. 265,266$)$ noted this species, as well as Batostoma winchelli spinulosum, in Black River and Trenton strata in New York. Caley (1936, p. 27) established two paleontologic zones in the Trentonian rocks of Manitoulin Island, the lower of which, 40 feet thick, is termed the $P$. simulatrix orientalis zone. According to Caley, this species is restricted to these beds on Manitoulin Island. In addition to P. simulatrix orientalis, Caley (1936, p. 29) recorded Dekayella praenuntia echinata and $B$. cf. winchelli from the Trenton of Manitoulin Island, which species are found also in the Spechts Ferry. Wilson (1921, p. 31) listed B. winchelli as a common fossil in the upper Leray beds of late Blackriveran age in the Ottawa Valley and $P$. simulatrix orientalis as an exceptionally common species in the lower beds of the Rockland of early Trentonian age from the same area. In an earlier publication, however, Wilson and Mather (1916, p. 49, 55) noted B. winchelli in both Blackriveran and Trentonian rocks of the Kingston area in southern Ontario. Finally, Sproule (1936, p. 104) recognized $P$. simulatrix orientalis from Coburg beds of Trentonian age in New York and southern Ontario.

This discussion indicates that on the basis of its bryozoans the age of the Spechts Ferry cannot be established definitely as either Blackriveran or Trentonian. This situation results primarily because the known stratigraphic ranges of its widely distributed species span the Black River-Trenton boundary and because there is inadequate knowledge of Middle Ordovician bryozoan faunas.

\section{Acknowledgments}

This study is part of a major investigation of the Middle Ordovician strata of Illinois by the Illinois State Geological Survey. I am grateful to Charles W. Collinson and H. B. Willman of the Survey for discussions of the stratigraphic problems and for direction to some of the collecting localities. Professor Emeritus J. J. Galloway of Indiana University assisted in some identifications. Technologic facilities, including photography by George Ringer of the Indiana Geological Survey, were provided by Indiana University. 


\title{
SYSTEMATIC PALEONTOLOGY
}

\author{
Order TREPOSTOMATA Ulrich, 1882
}

Suborder AMALGAMATA Ulrich \& Bassler, 1904

Family MONTICULIPORIDAE Nicholson, 1881

Genus HOMOTRYPA Ulrich, 1882

Type species: Homotrypa curvata Ulrich

HOMOTRYPA EXILIS Ulrich

Plate 1, figures $1-8$

Homotrypa exilis Ulrich, 1886, 14th Ann. Rept., Geol. Nat. Hist. Survey Minnesota, p. 80; Ulrich, 1895, Geol. Minnesota, v. 3, p. 236, pl. XIX, figs. 10-16.

External features. - Zoarium ramose, solid, and commonly showing dichotomous branching; fragments of zoarium commonly as much as $40 \mathrm{~mm}$ long and $12 \mathrm{~mm}$ in diameter. Surface smooth, showing maculae composed of mesopores and zooecia above average in size; maculae spaced from 3.0 to $4.5 \mathrm{~mm}$ apart, measuring from center to center.

Tangential section. - Zooecia angular to subangular, commonly with obscure outlines; zooecial apertures generally broadly and irregularly ovate, less commonly subcircular or slightly angular; typically (102 of 200 measurements on 20 specimens) eight entire zooecia and part of ninth in $2 \mathrm{~mm}$, measuring parallel to length of zoarium; commonly ( 61 of 200 measurements on 20 specimens) seven entire zooecia and portion of eighth in this distance; average maximum apertural diameter (based on 200 measurements on 20 specimens and not including zooecial walls) of zooecia $0.21 \mathrm{~mm}$, ranging from 0.15 to $0.26 \mathrm{~mm}$. Zooecial walls thick, usually ranging from

\section{EXPLANATION OF PLATE 1}

Figures 3 and 5 are X60; all others are X20.

Specimen number and collecting locality are shown in parentheses following explanation of each figure. For example, $(12 \mathrm{P} 192,6)$ refers to specimen $12 \mathrm{P} 192$ obtained from collecting locality 6 . Structures in photographs are not retouched.

Figure

1 - 8 Homotrypa exilis Ulrich. 1. Longitudinal section; note absence of diaphragms in outer part of axis and throughout most of submature region and locally developed crenulations in zooecial wall; cystiphragms are more abundant than normal for species $(12 \mathrm{P} 192,6) .2$. Small part of longitudinal section from mature zone $(12 \mathrm{P} 151,1) .3$. Figure 2 enlarged to show zooecial wall structure in mature zone $(12 \mathrm{P} 151,1)$. 4. Small area of tangential section $(12 \mathrm{P} 199,6)$. 5. Figure 4 enlarged to show details of wall structure $(12 \mathrm{P} 199,6) .6$. Longitudinal section (12P199, 6). 7. Tangential section $(12 P 199,6)$. 8. Tangential sections of one of nine specimens having more mesopores than customary for species; part of macula shows in top center $(12 \mathrm{Pl} 186,6)$. 

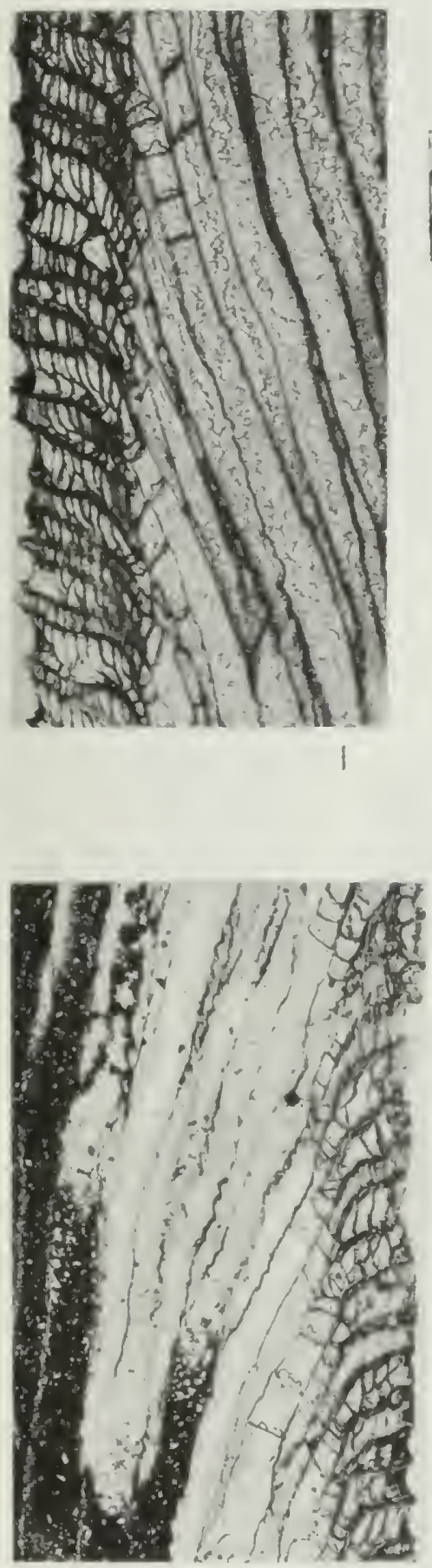

6

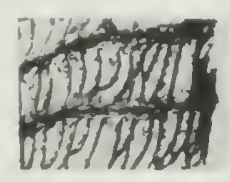

2

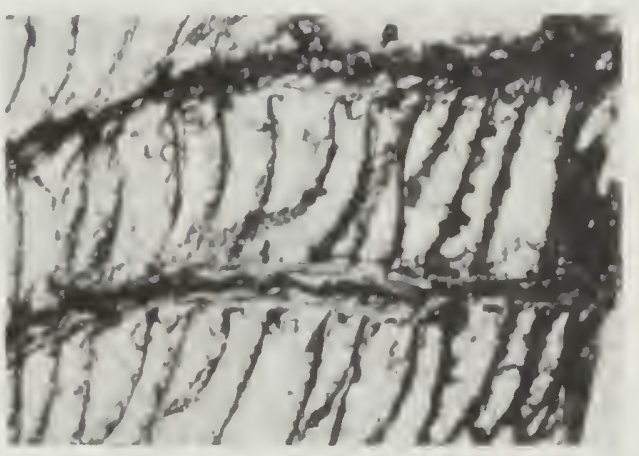

3
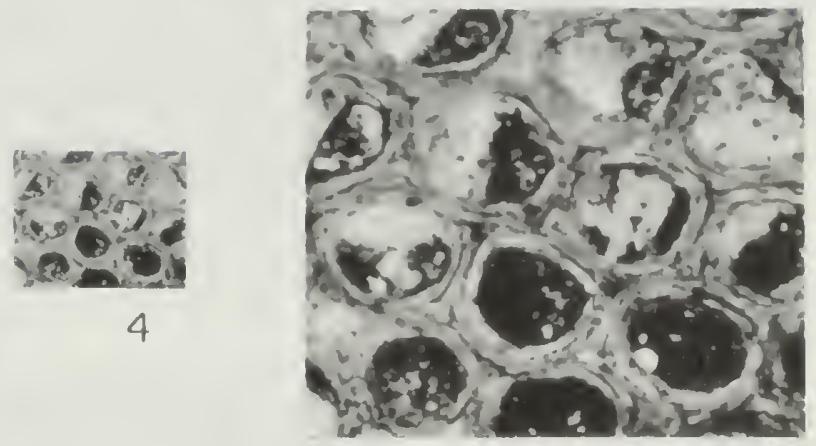

5
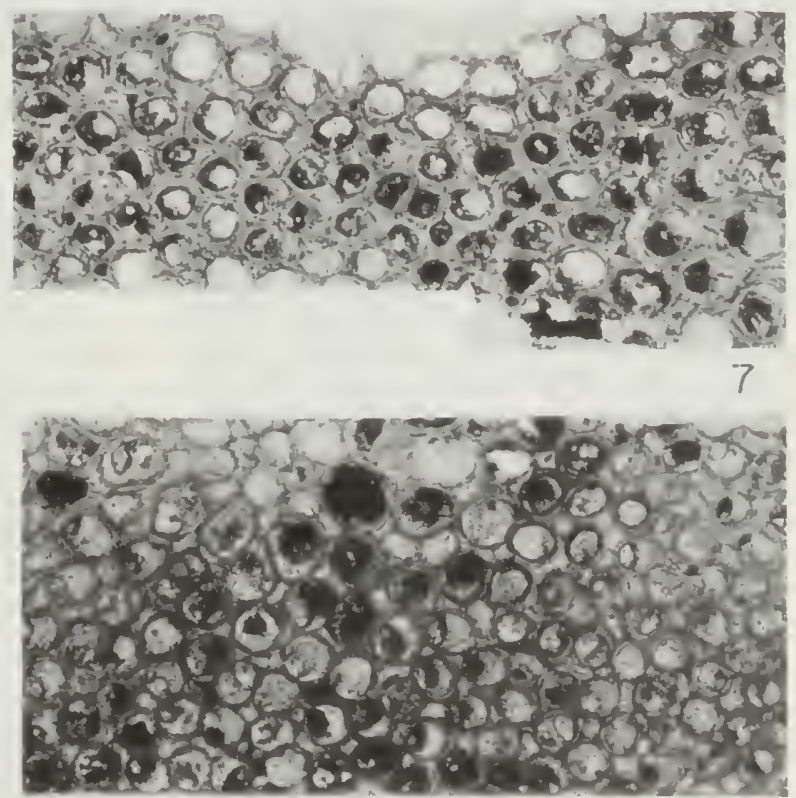

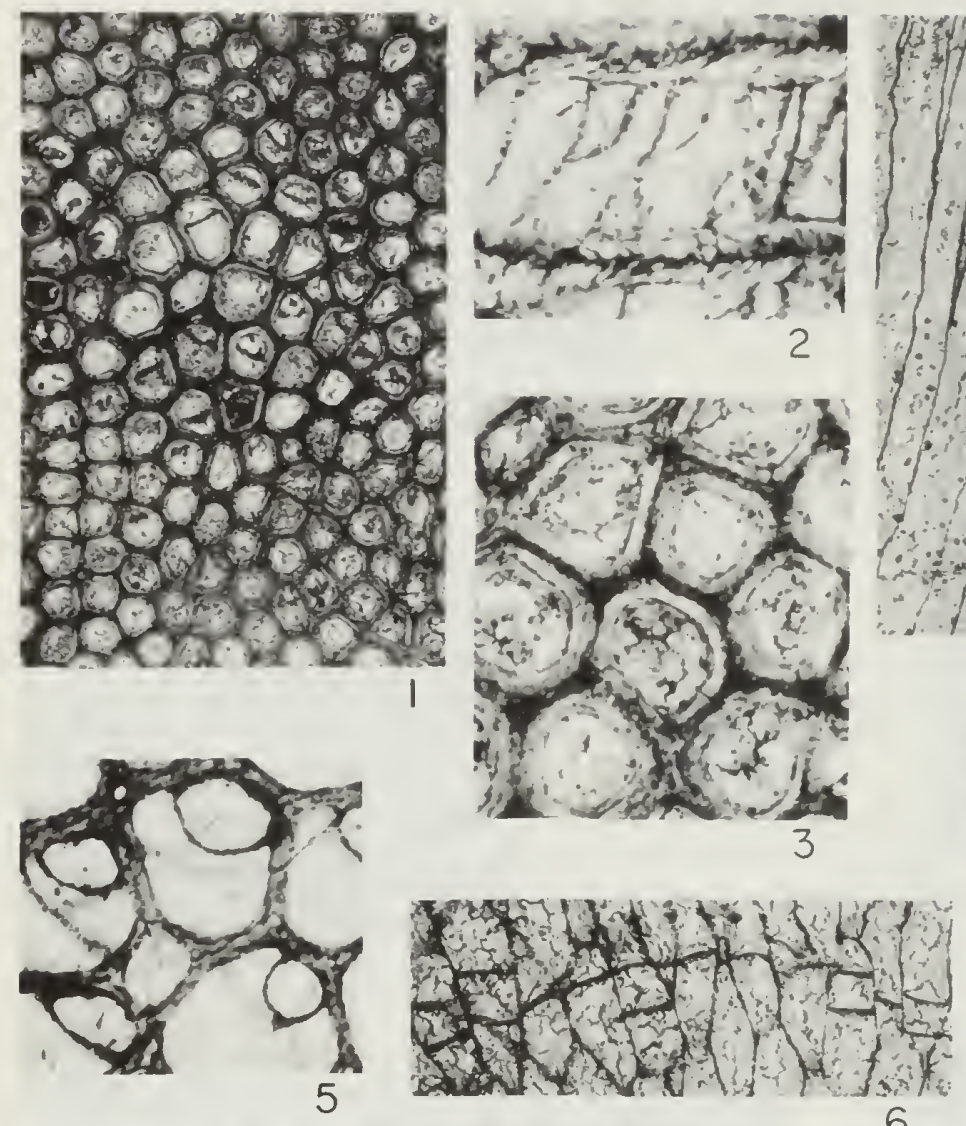

6
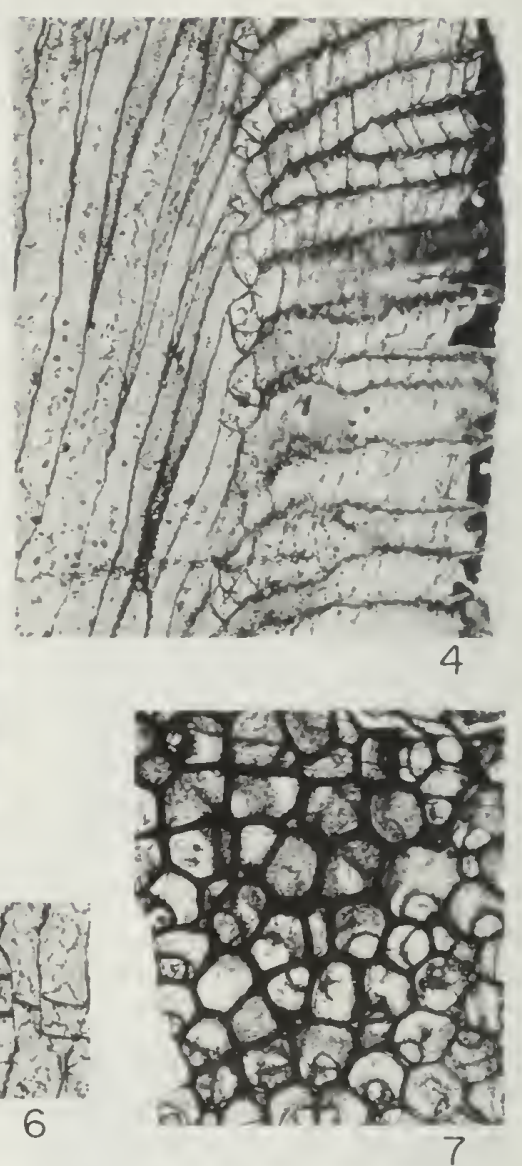

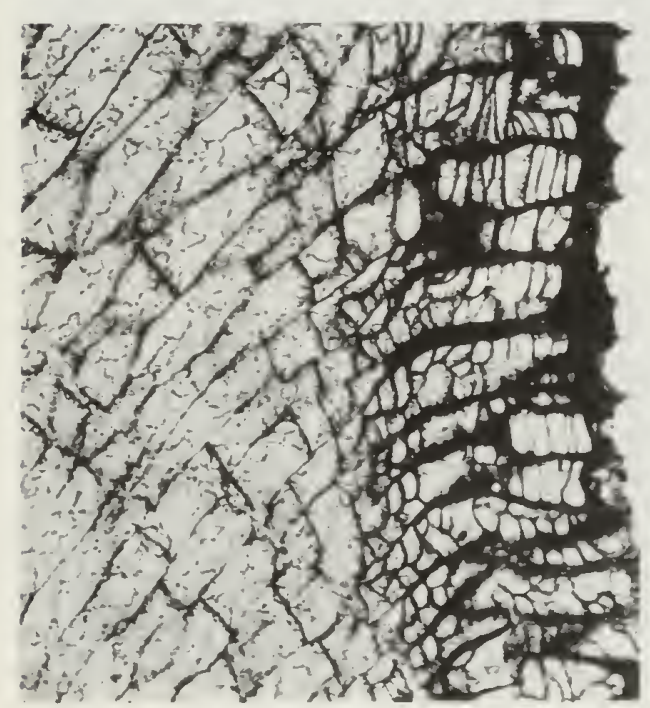

8

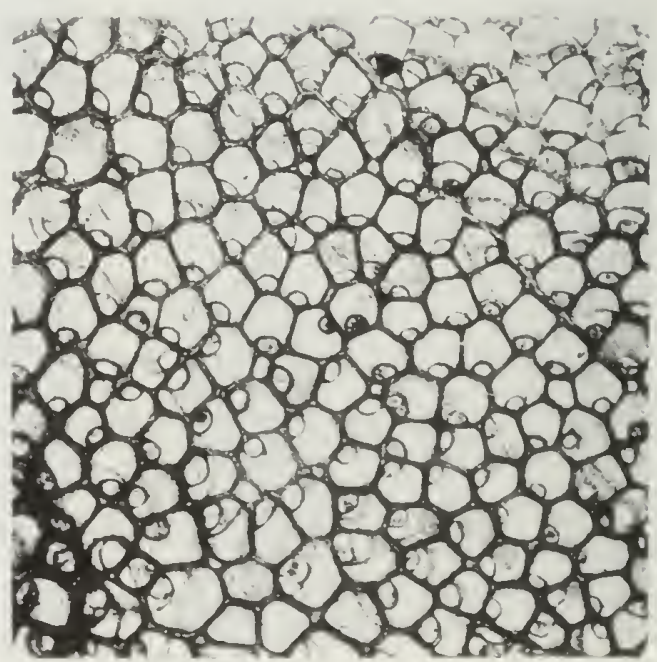

9 
0.03 to $0.06 \mathrm{~mm}$ in thickness but locally as much as $0.10 \mathrm{~mm}$ thick; walls somewhat more commonly amalgamate but may be integrate, particularly in local areas; cingulum commonly developed and composed of laminae concentrically disposed about zooecial aperture. Mesopores rare to uncommon, generally somewhat more numerous where zooecia have well developed cingula. Maculae commonly observed and represented by clusters of four to seven zooecia above average in size and intercalated mesopores. Acanthopores not definitely recognized.

Longitudinal section. - Zooecia straight and erect in axis, bending gradually to zoarial surface in submature zone and curving somewhat more abruptly near base of mature region. Zooecial walls thin in axis, commonly flexuous or rarely and locally crenulated, and thickening conspicuously and generally abruptly at base of mature zone; under high magnification ( $\times 210)$ wall vaguely and finely granular in axis but composed of laminae moderately to broadly convex outward in mature region; dark line or band, centrally located in zooecial wall, commonly developed. Cingulum of fine laminae nearly parallel to length of zooecium commonly forms outer part of zooecial wall; cingulum usually separated from primary wall material by thin, well developed black line. Where cingulum absent, wall laminae continuous into cystiphragms and diaphragms; where present, material of cingulum apparently continuous into these structures. Diaphragms lacking in axis, either lacking or widely spaced (usually $1 \frac{1}{2}$ to five zooecial diameters apart) in poorly defined submature zone, and closely spaced, generally one-half zooecial diameter apart or less, in mature zone where they range from about five to approximately 22 per

\section{EXPLANATION OF PLATE 2}

Figures 2, 3, and 5 are X60; all others are X20.

Specimen number and collecting locality are shown in parentheses following explanation of figure; for example, $(12 \mathrm{P} 129,2)$ refers to specimen $12 \mathrm{P} 129 \mathrm{ob}-$ tained from collecting locality 2. Structures in photographs are not retouched.

Figure

$1-4$

$5-9$
Homotrypa pauperata Perry, n. sp. 1. Tangential section of holotype showing well developed macula $(12 \mathrm{P} 129,2) .2$. Small part of longitudinal section showing characteristic zooecial wall structure in mature zone $(12 \mathrm{P} 129,2)$. 3. Small portion of tangential section showing nature of zooecial wall $(12 \mathrm{P} 129,2)$. 4. Longitudinal section displaying local development of flexuous zooecial walls, sparse occurrence of imperfectly formed cystiphragms, and lack of diaphragms in axis $(12 \mathrm{Pl} 29,2)$.

Homotrypa dickeyvillensis Perry, n. sp. 5. Tangential section of holotype showing typical appearance of cystiphragms and a single acanthopore $(12 \mathrm{P} 88,5)$. 6. Longitudinal section showing concentration of diaphragms at nearly the same level in the axial region $(12 \mathrm{P} 88,5)$. 7. Tangential section of holotype showing probable monticule in upper left quadrant $(12 \mathrm{P} 88,5)$. 8. Longitudinal section $(12 \mathrm{P} 88,5)$. 9. Tangential section displaying prominent cystiphragms; in upper right, section descends to near base of mature zone so zooecial walls are conspicuously thinner than el sewhere $(12 \mathrm{P} 88,5)$. 


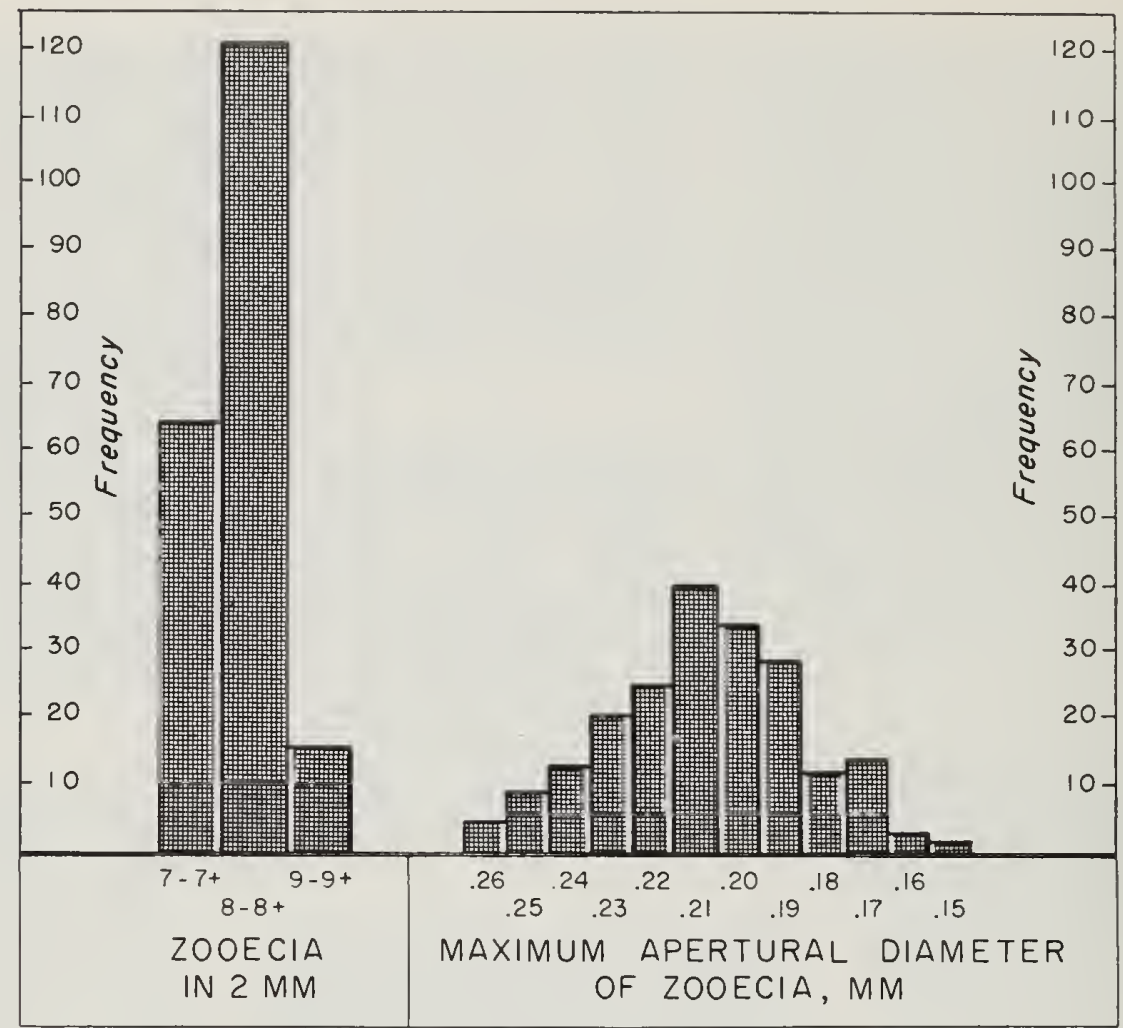

Text f1g. 1 - Measurements on Homotrypa exilis Ulrich. 7+ signifies seven entire zooecla and part of elghth in a $2-\mathrm{mm}$ distance.

zooecium, probably averaging from eight to 14 per zooecium. True cystiphragms thick, composed of laminae continuous with material of primary wall or secondarily formed cingulum, located in outer part of mature zone, usually not more than three to five per zooecium, and generally found only in a few zooecia in each specimen; cystiphragms arching outward and uniting proximal diaphragm to zooecial wall common in mature region. Mesopores rarely observed, closely tabulate, and confined to mature zone. Acanthopores not seen.

Remarks. - This species is characterized by its thick zooecial walls, lack of diaphragms in the axis, and the presumable absence of acanthopores; cingula are not uncommon. Mesopores are intercalated sparsely between zooecia in intermacular areas; in a few specimens, mesopores are distributed sporadically, as they are found sparingly in some areas of a tangential section but are absent in others.

This is the most abundant ramose form in the Spechts Ferry Shale of northwestern Illinois and adjacent parts of Wisconsin and Iowa. The foregoing description was based on intensive study of 20 specimens and somewhat more casual examination of 63 other forms. Text figure 1 shows measurements of a number of zooecia in a $2-\mathrm{mm}$ distance and maximum apertural diameter of the zooecia, exclusive of zooecial walls, for the 20 specimens that were studied critically.

In addition to these 83 specimens, nine others (12P13, 12P23, 12P24, 12P33, $12 \mathrm{P} 65,12 \mathrm{P} 73,12 \mathrm{P} 126,12 \mathrm{P} 134$, and $12 \mathrm{P} 186)$ are regarded as conspecific although 
differing somewhat from the characteristic structure of the species. These nine specimens have more abundant mesopores and somewhat smaller zooecial apertures than typical $H$. exilis. Zooecial apertures of these forms average $0.19 \mathrm{~mm}$ in maximum diameter exclusive of zooecial wall thickness, ranging from 0.14 to $0.24 \mathrm{~mm}$ for 80 measurements on eight specimens. Further, these specimens typically (34 of 80 measurements on eight specimens) have nine zooecia and part of a tenth in $2 \mathrm{~mm}$, measuring parallel to the length of the zoarium, and commonly ( 17 of 80 measurements on eight specimens) have either ten entire zooecia or ten complete zooecia and part of an eleventh in this distance. Text figure 2 gives measurements of the number of zooecia in a $2-\mathrm{mm}$ distance and maximum apertural diameter of the zcoecia, exclusive of the zooecial walls, for these specimens.

None of the Spechts Ferry specimens are assigned to H. minnesotensis, a species described (Ulrich, 1895, p. 235) from the "Lower Third" of the Trenton shales in the Minneapolis area. Although the diameter of some of the specimens under study is slightly over $3.0 \mathrm{~mm}$, many exceed $10 \mathrm{~mm}$ in diameter, and one attains a diameter of $18 \mathrm{~mm}$. The over-all size of the zoarium would suggest assignment of the specimens to $H$. minnesotensis and not to $H$. exilis, as Ulrich (1895, p. 236) stated that the former species ranges from 5 to $15 \mathrm{~mm}$ in diameter and the latter from 4 to $5 \mathrm{~mm}$. However, as $H$. minnesotensis has distinctly thin walls, the decidedly thick walls of the Spechts Ferry specimens militate strongly against their placement in $H$. minnesotensis. Except for differences in zooecial wall thickness and over-all size of the zoarium, $H$. minnesotensis and $H$. exilis are strikingly similar in structure, particularly when examined microscopically.

Distribution. - Localities $1,2,3,4,6,8$.

Types. - Hypotypes, Illinois State Geological Survey, 12P2, 12P3, 12P5, 12P6, 12P8, 12P13, 12P14, 12P16, 12P17, 12P18, 12P20, 12P22, 12P23, 12P24, 12P26, 12P27, 12P29, 12P30, 12P33, 12P39, 12P40, 12P43, 12P45, 12P48, 12P51, 12P52, 12P54, 12P55, 12P56, 12P58, 12P59, 12P61, 12P65, 12P71, 12P72, 12P73, 12P95,

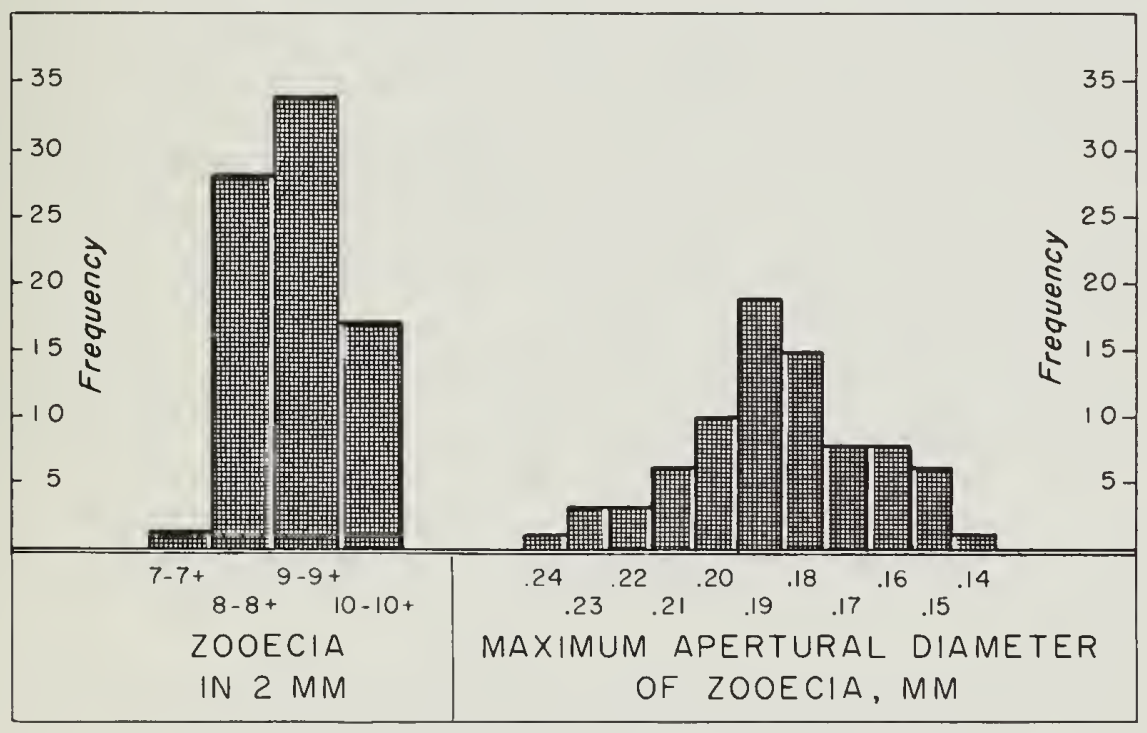

Text fig. 2 - Measurements on atypical forms of Homotrypa exilis Ulrich. 7+ signifies seven entire zooecia and part of eighth in a $2-\mathrm{mm}$ distance. 
12P97, 12P102, 12P103, 12P104, 12P105, 12P109, 12P110, 12P111, 12P117, 12P118, 12P119, 12P120, 12P123, 12Pl26, 12P127, 12P128, 12P130, 12P131, 12P134, 12P137, 12P138, 12P140, 12P142, 12P144, 12P145, 12P150, 12P151, 12P152, 12P153, 12P155, 12P157, 12P158, 12P159, 12P163, 12P164, 12P165, 12P167, 12P171, 12P173, $12 \mathrm{P} 174,12 \mathrm{P} 175,12 \mathrm{P} 176,12 \mathrm{P} 177,12 \mathrm{P} 179,12 \mathrm{P} 180,12 \mathrm{P} 183,12 \mathrm{P} 186,12 \mathrm{P} 188$, 12P189, 12P192, 12P193, 12P194, 12P196, 12P197, 12P199.

\section{HOMOTRYPA PAUPERATA PerTy, n. sp.}

Plate 2, figures $1-4$

External features. - Zoarium ramose, solid, elliptical in cross section, the largest incomplete specimen $12 \mathrm{~mm}$ in maximum diameter and $10 \mathrm{~mm}$ in minimum diameter and $39 \mathrm{~mm}$ long. Maculae, usually spaced 3.0 to $4.5 \mathrm{~mm}$ apart mea suring from center to center, composed mainly of about eight zooecia above average in size.

Tangential section. - Zooecia angular or subangular, very thick-walled, and having broadly ovate to subpolygonal apertures; most commonly (13 of 25 measurements) nine entire zooecia and part of tenth in $2 \mathrm{~mm}$, measuring parallel to length of zoarium; less commonly (nine of 25 measurements) ten entire zooecia and portion of eleventh in this distance; average maximum apertural diameter (based on 25 measurements) of zooecia $0.16 \mathrm{~mm}$, ranging from 0.14 to $0.19 \mathrm{~mm}$; average interapertural zooecial wall thickness (based on 20 measurements) nearly $0.07 \mathrm{~mm}$, ranging from 0.04 to $0.10 \mathrm{~mm}$. Zooecial wall composed of a broad, darkcolored band of fibrous and granular tissue flanked on either side by lighter colored laminated material, the laminae parallel to zooecial apertures. Maculae formed entirely of zooecia above average in size or of larger zooecia and a small number, usually one to four, of intercalated mesopores. Acanthopores not observed. Mesopores uncommon, thick-walled, and subpolygonal.

Longitudinal section. - Zooecia erect, thin-walled, straight or slightly flexuous in axis, thickening abruptly at base of mature zone where they bend sharply to zoarial surface. Zooecial wall in mature zone commonly but not invariably showing dark-colored divisional line between zooecia; wall material of fine laminae moderately to broadly convex outward. Diaphragms lacking in axis; ten to fifteen per zooecium in broad mature zone where diaphragm spacing approximates half zooecial diameter. Cystiphragms not present in all zooecia, generally terminating proximally at diaphragm and arching distally to unite with zooecial wall. Mesopores probably not observed. Acanthopores lacking.

Remarks. - Homotrypa pauperata and H. exilis Ulrich are closely allied species, as both have thick zooecial walls and presumably lack acanthopores. Distinguishing characteristics of the se species are: (1) cystiphragms are more abundant in $H$. exilis; (2) average zooecial wall thickness is greater in $H$. pauperata; (3) microstructure of the zooecial walls, particularly where observed in tangential section, differs in these species; (4) $H$. pauperata has fewer mesopores; and (5) $H$. pauperata has smaller zooecia and thus displays more of these structures in a $2-\mathrm{mm}$ distance than $H$. exilis.

The specific name pauperata means "impoverished" and alludes to the rather sparse development of cystiphragms. The species is represented in the Spechts Ferry collections by two specimens from which four tangential and two longitudinal sections were prepared.

Distribution. - Localities 2, 6 .

Types. - Illinois State Geological Survey; holotype 12P129, paratype 12P241. 
HOMOTRYPA DICKEYVILLENSIS Perry, n. sp.

Plate 2, figures 5-9

External features. - Zoarial fragment ramose, $14 \mathrm{~mm}$ wide and $32 \mathrm{~mm}$ long, and showing proximal part of one bifurcation; neither monticules nor maculae observed on weathered zoarial surface.

Tangential section. - Zooecia typically angular, rarely subangular, and having amalgamate walls that are usually 0.02 or $0.03 \mathrm{~mm}$ thick; generally (12 of 20 measurements) eight entire zooecia and portion of ninth in $2 \mathrm{~mm}$, measuring parallel to length of zoarium; less commonly (six of 20 measurements) seven entire zooecia and part of eighth in this distance; and rarely (one of 20 mea surements) seven or (one of 20 measurements) nine entire zooecia in $2 \mathrm{~mm}$. Cystiphragms prominent, observed in nearly all zooecia, and typically enclosing about one-sixth of the apertural area of each zooecium. Acanthopores generally sparse, moderately abundant in local areas, small, commonly at junction angles of adjoining zooecia, rarely mildly inflecting, and with thick, dark,opaque walls surrounding small hollow center. Where relatively abundant, generally one, less commonly two, acanthopores associated with each zooecium; where rare, one associated with ten or more zooecia. Two areas consisting of zooecia generally lacking cystiphragms and usually above average size probably represent monticules. Mesopores probably lacking, but small subangular or subround zooecia not uncommon.

Longitudinal section. - Zooecia thin-walled and locally crenulated or flexuous in mature and submature regions, becoming thicker walled at base of well defined mature zone. Locally zooecial walls appear integrate, showing centrally located somewhat undulatory dark line; shape or orientation of laminae in zooecial wall not discernible. Zooecia bend gradually to zoarial surface, the zooecial curvature increasing somewhat at base of mature region. Diaphragms very sparse in axis, two to four zooecial diameters apart in poorly defined submature zone, and one-half zooecial diameter apart, or less, in mature zone where each zooecium usually contains from seven to thirteen diaphragms. Cystiphragms prominent, commonly occupying one-half the width of each zooecium, usually in one series but rarely extending from both sides of the zooecium; earliest formed cystiphragms at base of mature region; material forming cystiphragms obscurely continuous with zooecial wall material. Mesopores not observed.

Remarks. - This species is characterized by its moderately thick zooecial walls and the sharply defined base of the mature zone, which is marked by thickening of zooecial walls, the abrupt appearance of well developed cystiphragms, and the closer spacing of the diaphragms. In tangential sections, cystiphragms are conspicuous structures in virtually all zooecia, except in larger zooecia forming the monticules in which cystiphragms are lacking or poorly developed. Zooecial walls in the axial and submature regions are commonly crenulated or wrinkled, as may be observed in many species of Homotrypa.

Homotrypa dickeyvillensis differs from all Bromide (late Blackriveran) species of Homotrypa described by Loeblich (1942, p. 420-422) in having diaphragms very sparsely developed in the axial region; diaphragms in Bromide species recognized by Loeblich, in contrast, are spaced three zooecial diameters apart, or less, in the axial region. H. dickeyvillensis does not compare closely with any Cincinnatian species of Homotrypa described by Bassler (1903, p. 565-591) or by Cumings and Galloway (1912, p. 429-432) nor does this species resemble forms described by Fritz (1957, p. 22, 23) from the Ottawa Formation (Black RiverTrenton) of the Ottawa-St. Lawrence Lowland. 
Homotrypa dickeyvillensis is related closely to H. subramosa and H. callosa described by Ulrich (1895, p. 239, 240; 243, 244). H.dickeyvillensis differs from $H$. subramosa in that the latter species has diaphragms spaced from one to three zooecial diameters apart in the axial region and may have more prominent and more abundant acanthopores. In H.dickeyvillensis, however, diaphragms are much more distantly spaced in the axis and display a tendency to occupy similar levels or horizons in adjacent zooecia throughout the width of the axial region. $H$. dickeyvillensis differs from $H$. callosa in the frequency of diaphragm occurrence in the axial region and in details of zooecial wall structure as observed in tangential section. Ulrich (1895, pl. 20, fig. 19) illustrates a specimen (presumably regarded by him as a cotype or paratype) of $H$. callosa that clearly has more abundant diaphragms in the axis than has $H$. dickeyvillensis. In tangential sections of $H$.dickeyvillensis, the thin black divisional line, so well developed in $H$. callosa (Ulrich, 1895, pl. 20, figs. 15, 20) is developed very sporadically and imperfectly; further, the granular wall structure (Ulrich, 1895, pl. 20, fig. 21) was not observed in tangential sections of $H$. dickeyvillensis.

This species is represented in the Spechts Ferry collections by one specimen from which two tangential and two longitudinal sections were prepared; a large fragment of the zoarium remains. The specific name alludes to the collecting site of the holotype, which is located near the village of Dickeyville in Grant County, southwestern Wisconsin.

Distribution. - Locality 5 .

Type.-Illinois State Geological Survey; holotype 12 P88.

\section{EXPLANATION OF PLATE 3}

Figure 5 is $\mathrm{X} 4$; figures 2 and 6 are $\mathrm{X} 60$; all others are $\mathrm{X} 20$.

Specimen number and collecting locality are shown in parentheses following explanation of each figure; for example, $(12 \mathrm{Pl} 162,8)$ refers to specimen $12 \mathrm{Pl} 162$ obtained from collecting locality 8 . Structures in photographs are not retouched.

Figure

1-6 Dekayella praenuntia echinata Ulrich. 1. Tangential section $(12 \mathrm{P} 162,8)$. 2. Small area of tangential section displaying excellent examples of larger set of acanthopores $(12 \mathrm{P} 148,4)$. 3. Longitudinal section $(12 \mathrm{P} 162,8) .4$. Tangential section showing part of monticule in upper third of lllustration $(12 \mathrm{P} 92,6)$. 5. Surface of zoarium showing monticule $(12 \mathrm{P} 154,1) .6$. Tangential section displaying acanthopores of two distinct sizes $(12 \mathrm{P} 121,4)$.

7 - 9 Prasopora simulatrix orientalis Ulrich. 7. Tangential section showing macula $(12 \mathrm{Pl}, 6)$. 8. Longitudinal section showing prominent cystiphragms and closely tabulate mesopores $(12 \mathrm{Pl}, 6)$. 9. Tangential section $(12 \mathrm{P} 15,4)$. 

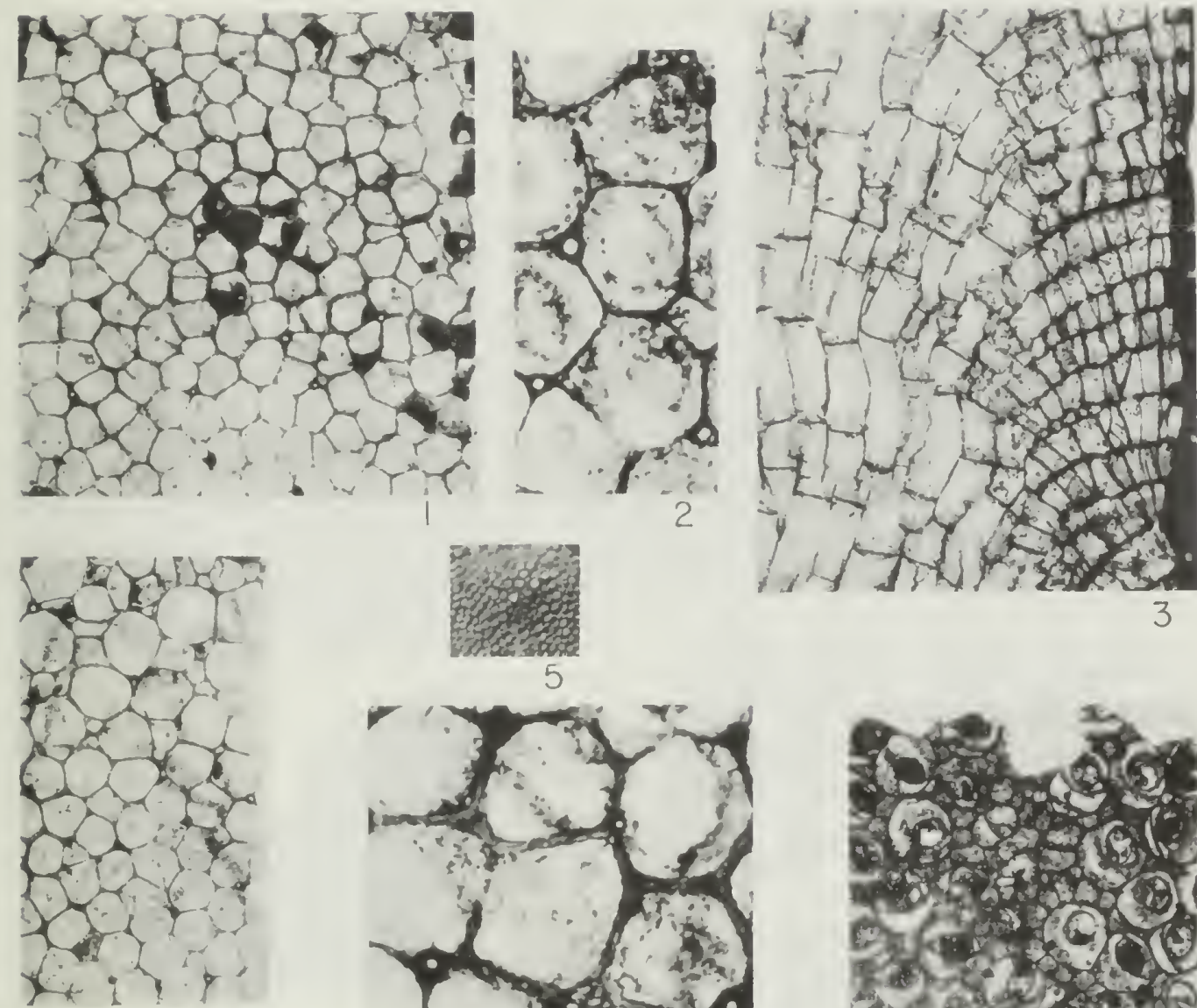

3

4

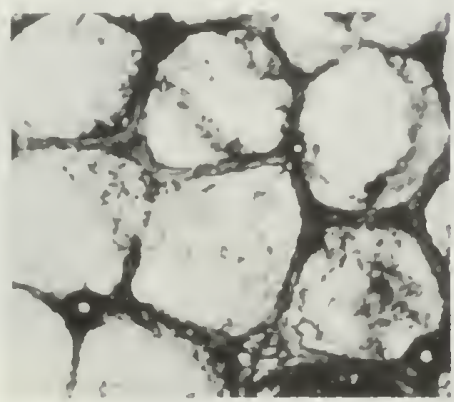

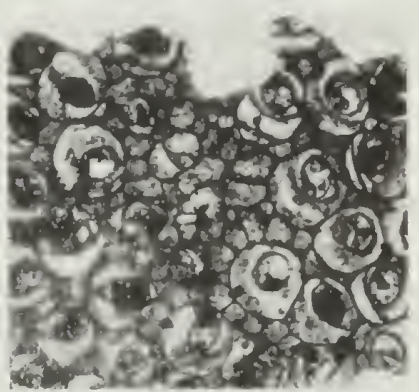

7
6

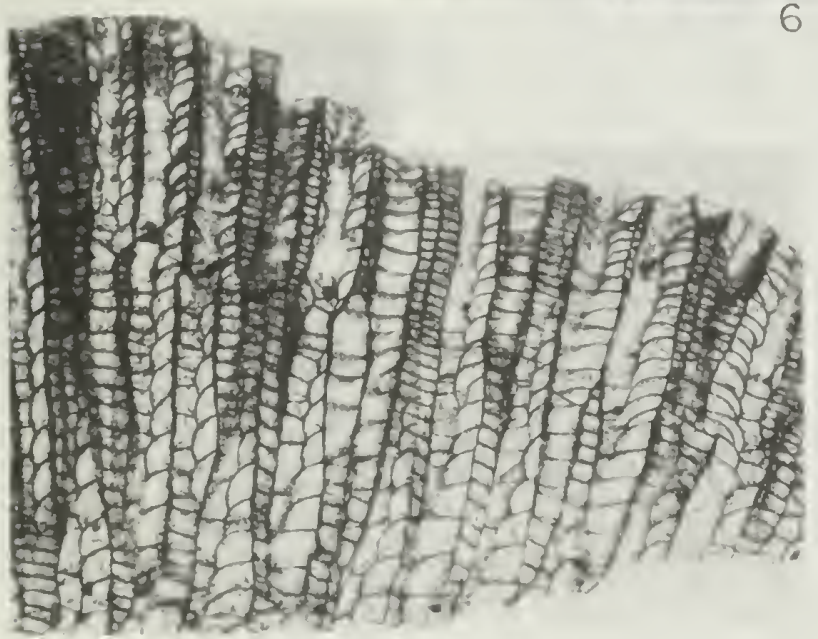

8

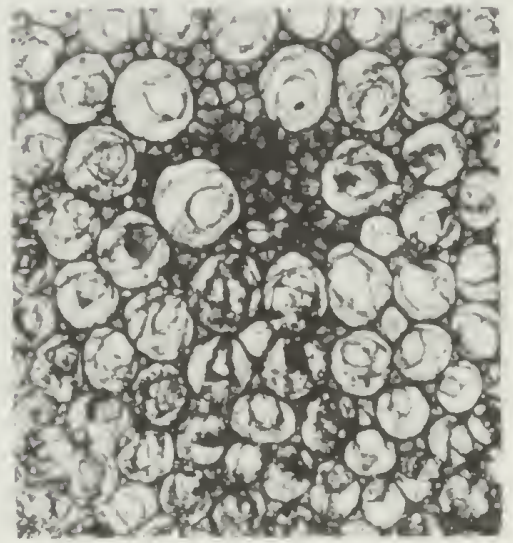

9 

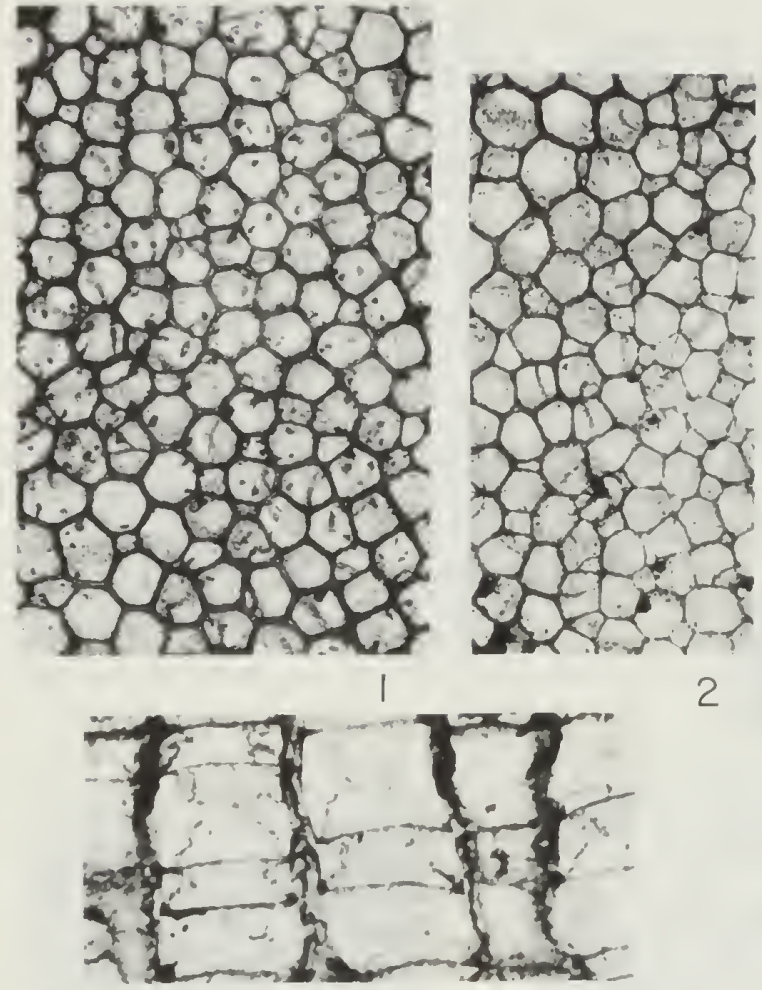

2
$140-12$ onth

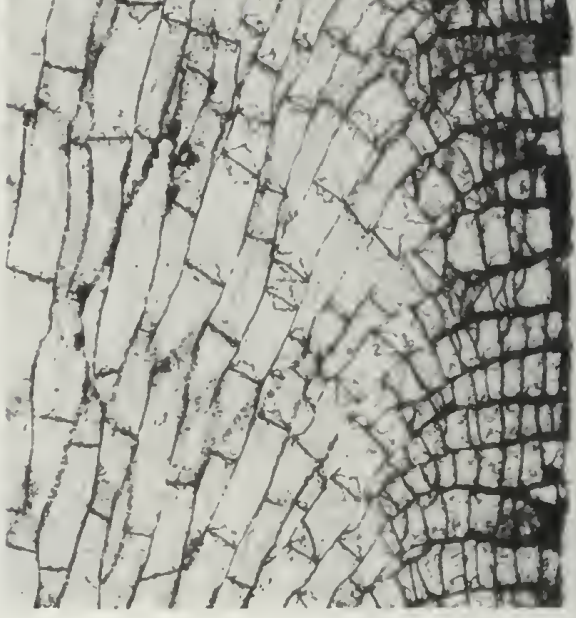

3
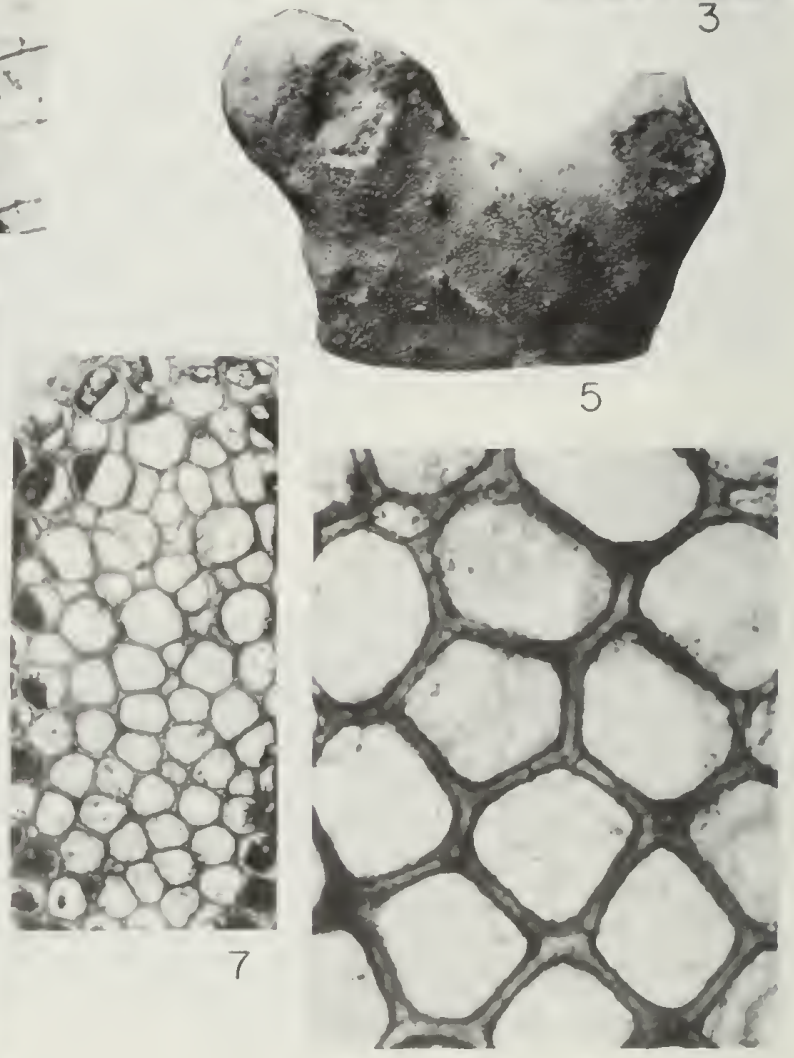

8 
Genus PRASOPORA Nicholson \& Etheridge, 1877

Type species: Prasopora grayae Nicholson \& Etheridge

PRASOPORA SIMULATRXX ORIENTALIS Ulrich

Plate 3, figures 7-9

Monticulipora (Diplotrypa) Whiteavesii Nicholson, 1879 (in part),

Pal. Tab. Corals, William Blackwood and Sons, Edinburgh

and London, p. 316, fig. 42c, pl. 14, fig. 1 .

Prasopora simulatrix var. orientalis Ulrich, 1895, Geol. Minnesota,

v. 3, p. 246, pl. XVI, figs. 1, 2, 6, 7; Wilson, 1921,

Geol. Survey Canada Bull. 33, pl. 3, figs. 1, 2; Fritz, 1957,

Geol. Survey Canada Bull. 42, p. 34, pl. XXXIII, figs. 2, 3.

External features. - Zoarium free, hemispherical, upper surface convex and concentrically wrinkled, lower surface concave; zoarium from 8 to $12 \mathrm{~mm}$ in diameter and from 1.8 to $3.9 \mathrm{~mm}$ thick. Low monticules or very slightly elevated maculae approximately $1 \mathrm{~mm}$ in maximum dimension, consisting of angular mesopores flanked by zooecia above average in size, and spaced from 3.0 to $4.5 \mathrm{~mm}$ apart, measuring from center to center.

Tangential section. - Zooecia round, broadly ovate, or somewhat subangular, having thin amalgamate walls; in intermacular areas most commonly (15 of 20 measurements) seven entire zooecia and portion of eighth in $2 \mathrm{~mm}$; less commonly (four of 20 measurements) eight entire zooecia and part of ninth in this distance; rarely (one of 20 measurements) six entire zooecia and part of seventh in $2 \mathrm{~mm}$; average maximum diameter (based on 30 measurements) of intermacular zooecia $0.26 \mathrm{~mm}$, ranging from 0.23 to $0.31 \mathrm{~mm}$; average maximum diameter (based on 24 measurements) of zooecia flanking maculae $0.37 \mathrm{~mm}$, ranging from 0.32 to $0.44 \mathrm{~mm}$. Adjacent zooecia almost invariably in contact locally. Mesopores angular, not exceeding one-quarter of the size of a typical zooecium and generally smaller; four

\section{EXPLANATION OF PLATE 4}

Figure 5 is X2; figures 4 and 8 are X60; all others are X20.

Specimen number and collecting locality are shown in parentheses following explanation of each figure; for example, (12P211, 10) refers to specimen 12 P21 obtained from collecting locality 10. Structures in photographs are not retouched.

Figure

$1-8$ Heterotrypa pauca Perry, n. sp. 1. Tangential section of holotype $(12 \mathrm{P} 211,10)$. 2. Tangential section displaying larger zooecia flanking monticule in upper left and thin-walled zooecia in lower right where section is locally below mature zone (12P211, 10). 3 . Longitudinal section of holotype $(12 \mathrm{P} 211,10)$. 4. Longitudinal section $(12 \mathrm{P} 185,8)$. 5. Surface of zoarium showing monticules $(12 \mathrm{P} 228,6)$. 6. Longitudinal section in which mesopores are more abundant than normal for species $(12 \mathrm{P} 178,8)$. 7. Tangential section showing well developed monticule in upper third of illustration $(12 \mathrm{P} 178,8)$. 8. Tangential section showing zooecial wall structure, small acanthopores and a single mesopore $(12 \mathrm{P} 70,6)$. 
to nine, most commonly six or seven, mesopores associated with each zooecium; maculae consisting of irregularly angular mesopores bordered by zooecia above average in size. Acanthopores absent or extremely minute.

Longitudinal section. - Zooecia thin-walled throughout length, somewhat inclined in earliest development but rapidly becoming erect. Cystiphragms conspicuous, commonly extending across half the width, or somewhat farther, of each zooecium, six to 14 , generally eight to 11 , in $1.0 \mathrm{~mm}$, and commonly lining one side of zooecium only. Diaphragms in zooecia usually less than one zooecial diameter apart, particularly in lower part of zoarium, but in some zooecia may be three or four zooecial diameters apart in upper portion of zoarium. Mesopores closely tabulate, from six to 15 , commonly 10 to 12 , diaphragms in $0.5 \mathrm{~mm}$. Acanthopores not observed.

Remarks. - In all respects except size of zoarium the Spechts Ferry specimens agree well with Prasopora simulatrix var. orientalis as described by Ulrich. Representatives of this variety are commonly much larger than specimens described herein; forms under study, however, fall within the size range of the species (Ulrich, 1895, p. 245). The small size of the Spechts Ferry specimens does not necessarily result from unknown ecologic factors, as Fritz (1957, p. 35) reports that this variety attains a subconical form after having passed through discoidal or hemispherical stages. Presumably the Spechts Ferry specimens could represent zoaria in a youthful stage of development. In zoarial form and size the described specimens resemble $P$. lenticularis Ulrich but cannot be assigned to this species, which has larger and fewer mesopores than the Spechts Ferry material.

Prasopora simulatrix orientalis is rare in the Spechts Ferry as the collections contain only three specimens from which five thin sections were prepared.

Distribution. - Localities 4, 6 .

Types. - Hypotypes, Illinois State Geological Survey, 12P1, 12P15, 12P21.

Family HETEROTRYIDAE Ulrich, 1890

Genus DEKAYELLA Ulrich, 1882

Type species: Dekayella obscura Ulrich

DEKAYELLA PRAENUNTIA ECHINATA Ulrich

Plate 3 , figures $1-6$

Dekayella praenuntia var. echinata Ulrich, 1895, Geol. Minnesota, v. 3, pt. 1, p. 271, pl. XXIII, figs. 32-38; Caley, 1936, Geol. Survey Canada Mem. 202, pt. II, p. 73, pl. 3, fig. 9, pl. 5, figs. 4-6; Loeblich, 1942, Jour. Paleontology, v. 16, no. 4, p. 426, pl. 63, figs. 12-14; Fritz, 1957, Geol. Survey Canada Bull. 42, p. 14, pl. VI, figs. 1, 2 .

External features. - Zoarium ramose, the largest fragment $31 \mathrm{~mm}$ long, 12 $\mathrm{mm}$ in greatest diameter, and $20 \mathrm{~mm}$ wide in region where two branches originate. Monticules rarely observed on weathered surface, very slightly elevated, and composed of zooecia somewhat above average in size surrounding an aggregation of mesopores or of zooecia somewhat larger than ordinary; monticules spaced about $3 \mathrm{~mm}$ apart, measuring from center to center.

Tangential section. - Zooecia sharply angular to subangular and having amalgamate walls usually ranging in thickness from slightly less than 0.01 to 
$0.02 \mathrm{~mm}$ but very rarely exceeding $0.03 \mathrm{~mm}$ thick; typically ( 31 of 50 measurements) eight entire zooecia and portion of a ninth in $2 \mathrm{~mm}$, measuring parallel to length of zoarium; much less commonly (10 of 50 measurements) seven entire zooecia and part of eighth or (nine of 50 measurements) nine entire zooecia and portion of a tenth in this distance. Mesopores angular to subround, generally ranging in size from one-fifth to nearly one-half the size of a typical zooecium, sporadically distributed, commonly two or three per zooecium but probably averaging about one or less. Acanthopores generally at junction angles of adjoining zooecia, of two distinct sizes with very few of intermediate size; larger acanthopores inflecting, as much as $0.10 \mathrm{~mm}$ in diameter but averaging about $0.06 \mathrm{~mm}$, usually about three times the size of the smaller acanthopores and probably at least four times as abundant as the smaller; acanthopores of both sizes irregularly distributed, as many as two or three per zooecium or absent or very rare in local areas, and having thick nearly opaque walls of concentrically fibrous material surrounding a hollow center. Local areas, approximately $1.5 \mathrm{~mm}$ in diameter, composed of small angular tubes flanked by zooecia above average in size or of zooecia larger than ordinary, represent monticules.

Longitudinal section. - Zooecia erect in axis and bending gradually to meet zoarial surface at right angles. In axis, zooecial walls thin, loosely flexuous, becoming slightly thicker where zooecia bend somewhat more abruptly toward zoarial surface. Laminae of zooecial walls moderately to broadly convex outward; where moderately convex, dark, poorly defined divisional line developed in wall between zooecia; wall laminae obscurely continuous into diaphragms. In axial region, diaphragms variably spaced, from two to five zooecial diameters apart in some zooecia and virtually absent in others; diaphragms in ill-defined mature zone average slightly more than half a zooecial diameter apart. Mesopores not commonly observed, confined to mature zone, and having somewhat more closely spaced diaphragms than the zooecia.

Remarks. - Dekayella praenuntia echinata is characterized by the sporadic distribution of mesopores and acanthopores; both structures are locally sparse or lacking, but in other parts of the zoarium may be moderately abundant. This species is represented in the Spechts Ferry collections by five specimens, from which nine thin sections were prepared.

Distribution. - Localities 1, 4, 6, 8, 9.

Types. - Hypotypes, Illinois State Geological Survey, 12P92, 12P121, $12 \mathrm{P} 148,12 \mathrm{P} 154,12 \mathrm{Pl} 22$.

\section{DEKAYELLA sp.}

\section{Plate 6, figures $1-3$}

External features. - Not adequately observed because specimen was largely embedded in shale matrix. Zoarium apparently irregularly ramose or bulbous, $26 \mathrm{~mm}$ long and $10 \mathrm{~mm}$ in maximum diameter.

Tangential section. - Zooecia sharply angular, less commonly subangular, and generally having thin walls; locally zooecial walls of moderate thickness $(0.02 \mathrm{~mm})$ and amalgamate; most commonly (five of ten measurements) seven entire zooecia and part of eighth in $2 \mathrm{~mm}$, and less commonly (three of ten measurements) eight complete zooecia and portion of ninth or (two of ten measurements) nine entire zooecia and part of tenth in this distance. Acanthopores exceptionally abundant, usually three to five but as many as seven associated with each zooecium, of two distinct sizes, and located at junction angles of adjoining zooecia; the larger 
acanthopores conspicuously inflecting zooecial apertures, about twice as abundant as the smaller set, commonly $0.05 \mathrm{~mm}$ in diameter, and having thick dark walls of concentrically fibrous material surrounding hollow center. Small tubes (presumably me sopores) nearly lacking in some areas of section but elsewhere moderately abundant. Evidence of either monticules or maculae not observed.

Remarks. - Three longitudinal sections were prepared, but none can be interpreted satisfactorily because of poor orientation, which precludes specific identification. The specimen is assigned to the genus Dekayella as it has acanthopores of two distinct sizes. This form clearly differs from D. praenuntia echinata Ulrich in having considerably more numerous acanthopores and thinner zooecial walls.

Distribution. - Locality 5 .

Described specimen .- Illinois State Geological Survey, 12P87.

Genus HETEROTRYPA Nicholson, 1879

Type species: Heterotrypa frondosa (d'Orbigny)

HETEROTRYPA PAUCA Perry, n. sp.

Plate 4 , figures $1-8$

External features. - Zoarium ramose, the fragments as much as $16 \mathrm{~mm}$ in diameter, $44 \mathrm{~mm}$ in length, and commonly showing areas of bifurcation. Surface smooth or showing low monticules composed of zooecia above average in size and intercalated mesopores; monticules spaced 3.0 to $4.0 \mathrm{~mm}$ apart, measuring from center to center. Where smooth, zoarial surface with clusters of zooecia of above average size and associated mesopores.

Tangential section. - Zooecia angular to subangular, generally five- or six-sided, and having amalgamate walls that commonly are 0.02 or $0.03 \mathrm{~mm}$ thick; central portion of zooecial wall composed of light-colored laminated material that is flanked on either side by thin zone of dark-colored laminated tissue; typically (110 of 200 measurements) eight entire zooecia and portion of ninth in $2 \mathrm{~mm}$, measuring parallel to length of zoarium. Acanthopores small-to medium-sized, sparsely

\section{EXPLANATION OF PLATE 5}

Figures 3 and 5 are X60; all others are X20.

Specimen number and collecting locality are shown in parentheses following explanation of each figure; for example, $(12 \mathrm{P} 68,6)$ refers to specimen $12 \mathrm{P} 68$ obtained from collecting locality 6 . Structures in photographs are not retouched.

\section{Figure}

$1-3$

$4-6$

$7-8$
Monotrypella normalis Perry, n. sp. 1. Tangential section of holotype showing macula in upper right of illustration $(12 \mathrm{P} 68,6) .2$. Longitudinal section $(12 \mathrm{P} 68,6)$. 3. Small part of transverse (axial) section showing dark-colored line of demarcation (divisional line) of zooecial wall in mature zone $(12 \mathrm{P} 68,6)$.

Batostoma winchelli spinulosum Ulrich. 4. Tangential section (12P219, 9). 5. Tangential section showing prominent and abundant acanthopores $(12 \mathrm{P} 219,9)$. 6. Longitudinal section (12P219, 9).

Diplotrypa sp. 7. Tangential section (12P207, 10). 8. Longitudinal section showing mesopores (12P207, 10). 

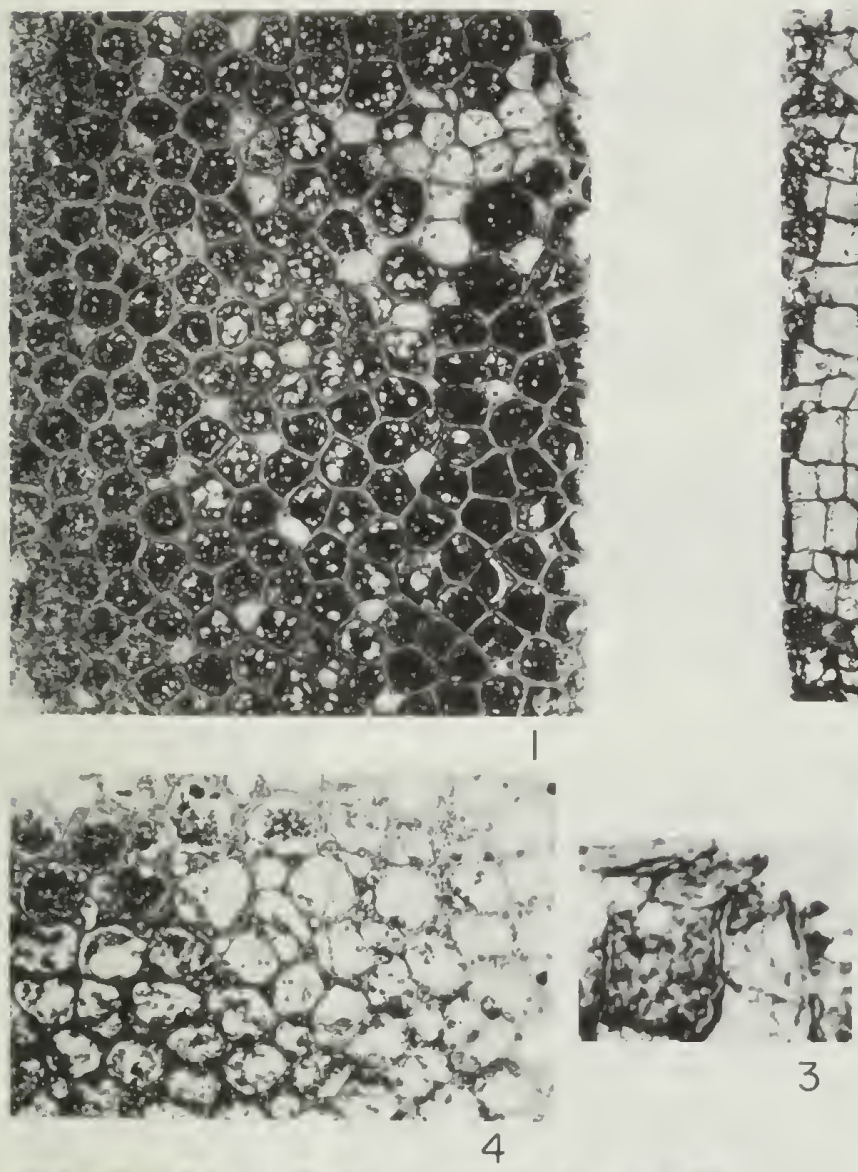

3

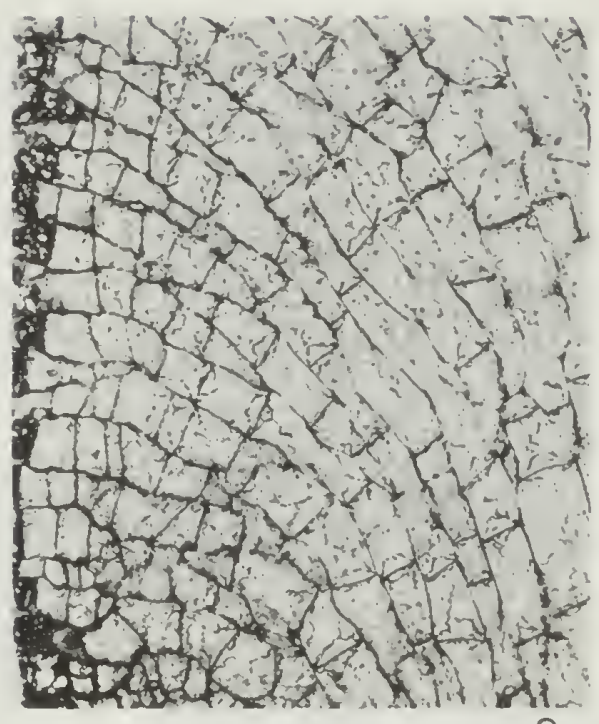

2
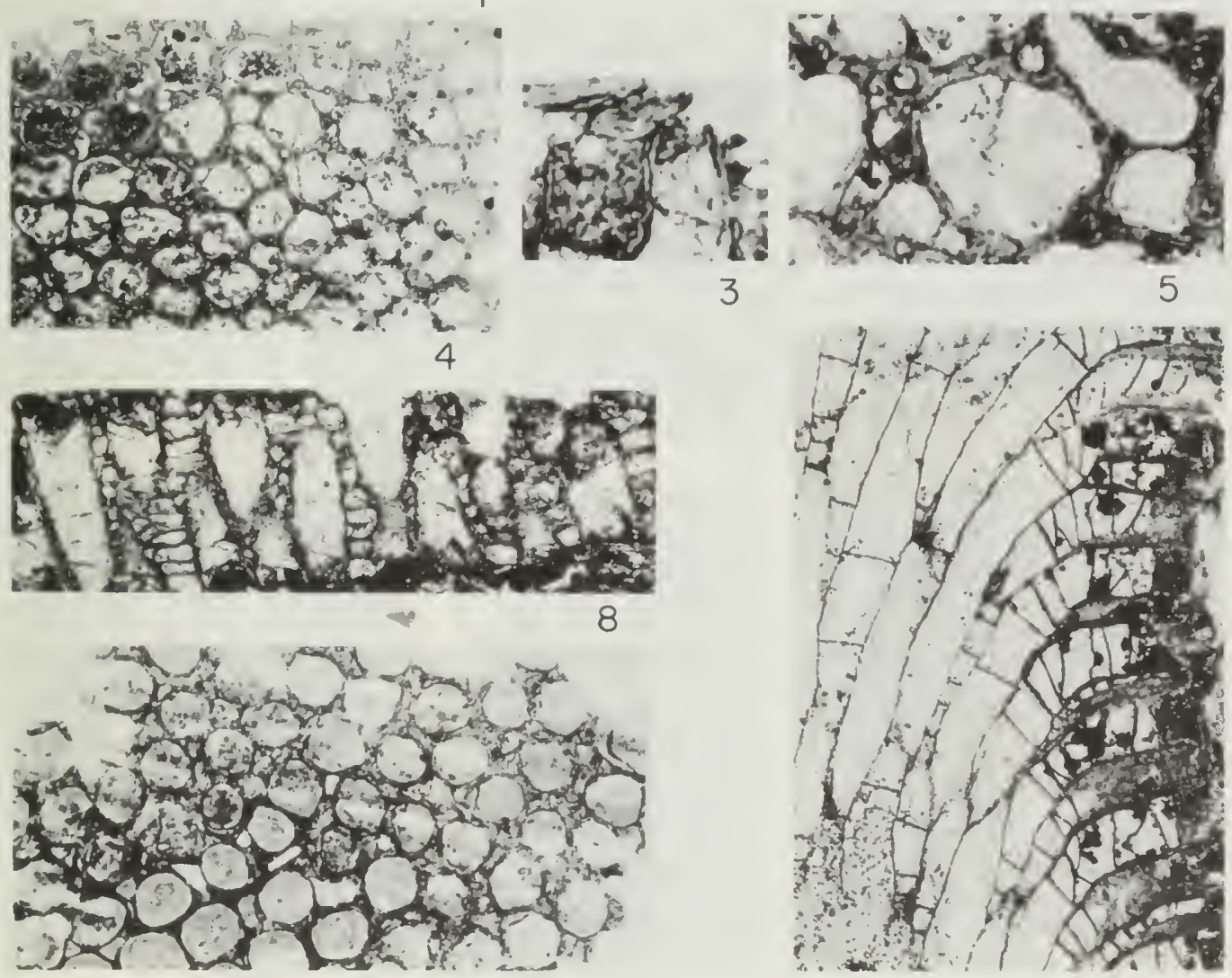

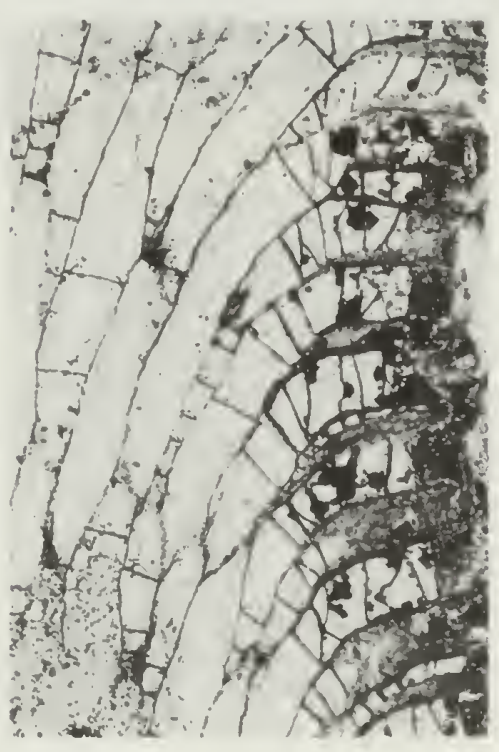

6 

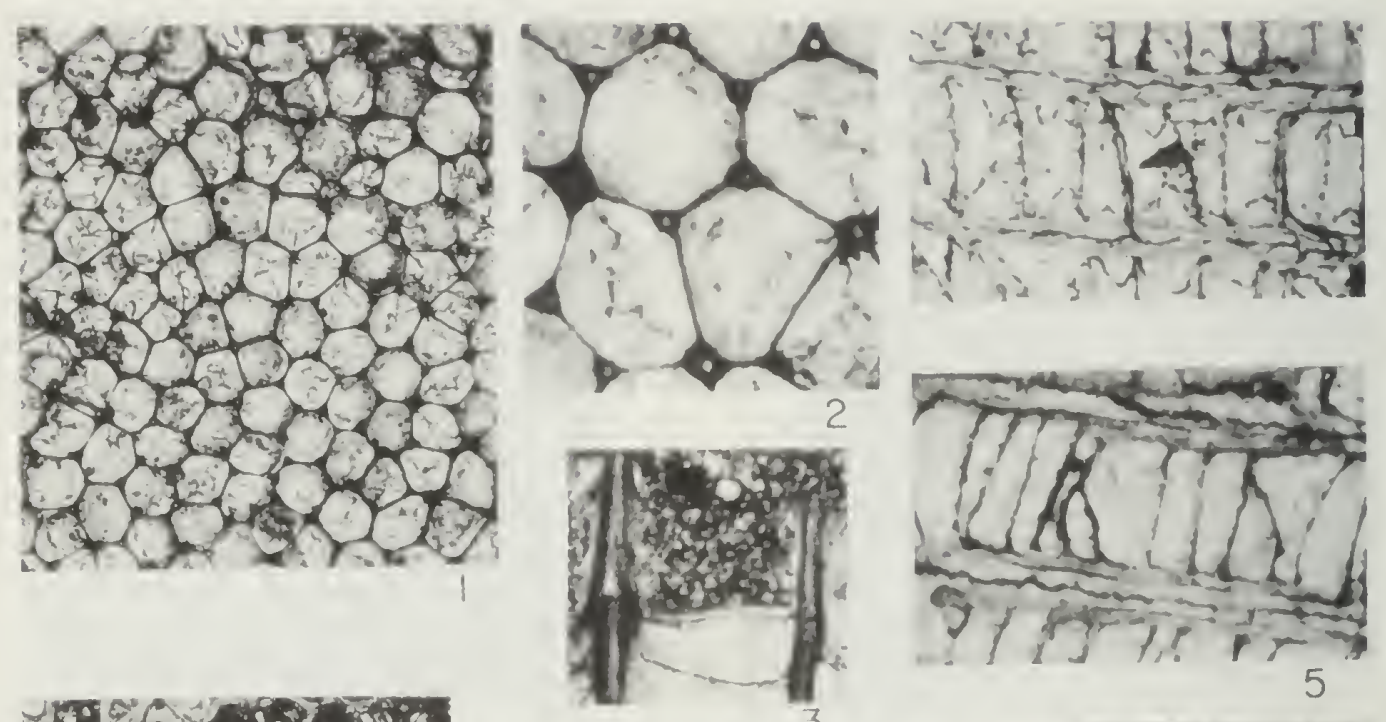

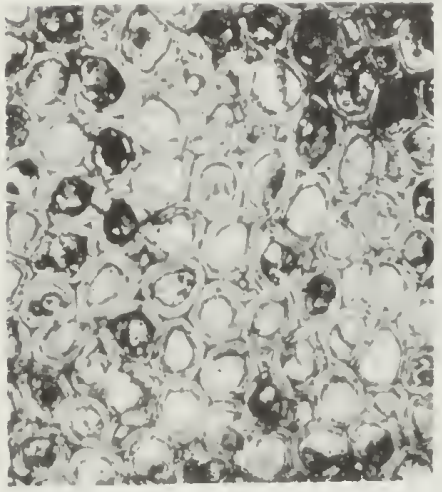

6

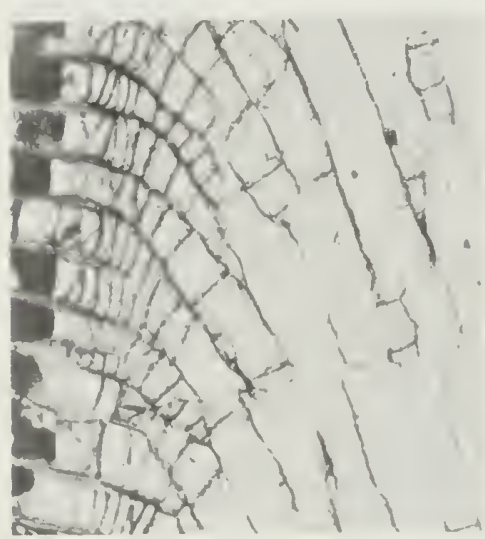

9
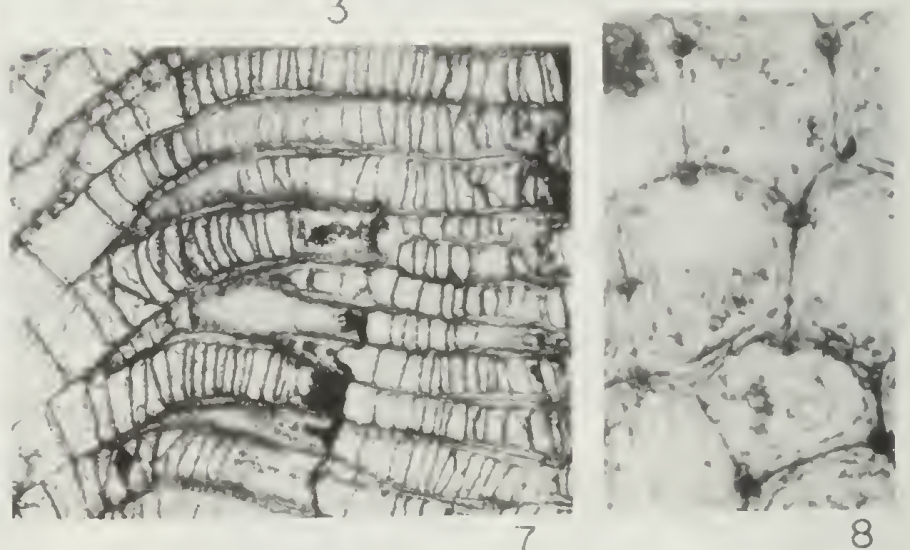

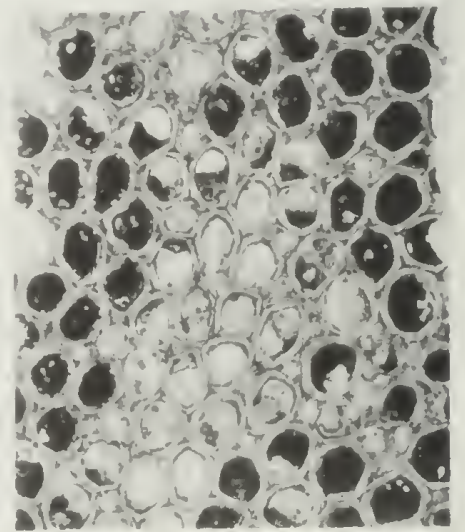

II 
developed and irregularly distributed, typically at junction angles of adjoining zooecia, commonly none to three, very rarely as many as six, associated with ten zooecia; acanthopore wall of dark, nearly opaque, concentrically laminated tissue differentiated sharply from zooecial wall material. Mesopores subovate to subangular, few, ten intermonticular zooecia commonly lacking an associated mesopore. Monticules consisting of clustered mesopores flanked by zooecia above average in size.

Longitudinal section. - Zooecial walls in axis thin, straight or mildly flexuous, and thickening gradually toward zoarial surface; zooecial walls in mature zone of fine laminae, moderately to broadly convex outward, and continuous into diaphragms. Zooecia erect in axis, curving gradually outward, and meeting zoarial surface at right angles. Diaphragms generally spaced one-half zooecial diameter apart in mature zone and from one to three zooecial diameters apart in submature region; diaphragms of variable abundance in axis, virtually lacking in a few zooecia, but customarily spaced from three to seven zooecial diameters apart; locally diaphragms arched, convex outward, and uniting with adjacent proximal diaphragm. Mesopores rare, containing closely spaced diaphragms, and not observed below mature region.

Remarks. - Heterotrypa pauca is represented in the Spechts Ferry collections by 20 sectioned specimens. This species may be identified by its thick amalgamate walls, its sparse and irregularly distributed acanthopores, and its few mesopores. In tangential sections of some specimens, acanthopores are so exceptionally rare that only two or three of these structures are observed in an entire section that may include several hundred zooecia. A few specimens are assigned to this species although acanthopores are not seen in their tangential sections; such specimens, however, are similar structurally in all other respects to forms that show rarely developed acanthopores. $H$. pauca has fewer acanthopores than any other described species of Heterotrypa of Ordovician age. The number of zooecia

\section{EXPLANATION OF PLATE 6}

Figures $2-5$ and 8 are X60; all others are X20.

Specimen number and collecting locality are shown in parentheses following explanation of each figure; for example, $(12 \mathrm{P} 87,5)$ refers to specimen $12 \mathrm{P} 87$ obtained from collecting locality 5 . Structures in photographs are not retouched.

Figure

$1-3$

Dekajella sp. 1. Tangential section $(12$ P87, 5). 2. Tangential section showing abundant acanthopores of two distinct sizes $(12 \mathrm{P} 87,5)$. 3. Small part of zooecial wall in mature zone showing acanthopores and zooecial wall structure $(12 \mathrm{P} 87,5)$.

4- 11 Batostoma winchelli (Ulrich). 4. Longitudinal section showing integrate zooecial wall of mature zone $(12 \mathrm{P} 156,8)$. 5. Longitudinal section displaying cingulum $(12 \mathrm{P} 198,6)$. 6. Tangential section showing distinctly integrate zooecial walls $(12 \mathrm{P} 198,6) .7$. Longitudinal section $(12 \mathrm{P} 198,6)$. 8. Tangential section showing integrate zooecial walls and mildly inflecting acanthopores $(12 \mathrm{P} 218,10) .9$. Longitudinal section $(12 \mathrm{P} 67,6)$. 10. Tangential section showing development of acanthopores characteristic of species $(12 \mathrm{P} 67,6)$. 11. Tangential section displaying integrate zooecial walls and inconspicuous acanthopores $(12 \mathrm{P} 191,6)$. 
in a 2 -mm distance, measured parallel to the length of the zoarium, is variable from six entire zooecia and a portion of a seventh (one of 200 measurements) to nine complete zooecia and a part of a tenth ( 41 of 200 measurements). The base of the mature zone is not defined crisply, but its position can be placed approximately where diaphragm spacing diminishes most noticeably.

The specific name alludes to the paucity of the acanthopores.

Distribution. - Localities 2, 4, 6, 7, 8, 10 .

Types. - Illinois State Geological Survey, holotype 12P211; paratypes 12P7, $12 \mathrm{P} 9,12 \mathrm{P} 69,12 \mathrm{P} 70,12 \mathrm{P} 74,12 \mathrm{P} 93,12 \mathrm{P} 96,12 \mathrm{P} 108,12 \mathrm{P} 133,12 \mathrm{Pl} 66,12 \mathrm{Pl} 68$, $12 \mathrm{P} 169,12 \mathrm{P} 178,12 \mathrm{P} 185,12 \mathrm{P} 202,12 \mathrm{P} 213,12 \mathrm{P} 217,12 \mathrm{P} 226,12 \mathrm{P} 228$.

Suborder INTEGRATA Ulrich \& Bassler, 1904

Family AMPLEXOPORIDAE Miller, 1889

Genus MONOTRYPELLA Ulrich, 1882

Type species: Monotrypella aequalis Ulrich

MONOTRYPELLA NORMALIS Perry, n. sp.

Plate 5, figures $1-3$

External features. - Zoarium ramose, solid, the larger of two fragments $21 \mathrm{~mm}$ long and $11 \mathrm{~mm}$ in maximum diameter. Surface smooth, exhibiting maculae that are 4.0 to $5.0 \mathrm{~mm}$ apart, measuring from center to center, and composed of zooecia above average in size and intercalated smaller cells.

Tangential section. - Zooecia angular to somewhat subangular and generally five- or six-sided; most commonly (14 of 20 measurements) nine entire zooecia and part of tenth in $2 \mathrm{~mm}$, measuring parallel to length of zoarium; less commonly (four of 20 measurements) eight complete zooecia and part of ninth or more rarely (two of 20 measurements) ten entire zooecia and portion of eleventh in this distance. Zooecial walls thin $(0.01$ to $0.02 \mathrm{~mm})$, composed of fine laminae paralleling margins of zooecial apertures, and generally appearing amalgamate but locally clearly integrate. Angular to subround cells, smaller than average zooecia, and simulating mesopores are common. Areas of zooecia above average in size and intercalated smaller cells represent maculae. Acanthopores lacking.

Longitudinal section. - Zooecia erect, thin-walled in axis, and bending gradually toward zoarial surface, the curvature increasing somewhat at base of mature zone where zooecial wall thickness increases and diaphragm spacing diminishes. Zooecial wall in mature zone composed of laminae acutely to moderately convex outward and usually clearly integrate; wall laminae continuous into diaphragms; line of demarcation narrower and more sharply defined where zooecial wall laminae are acutely convex outward, wider and somewhat vaguely defined where wall laminae are more broadly convex outward. Diaphragms in axis usually spaced from two to six zooecial diameters apart but lacking through a distance as much as $4 \mathrm{~mm}$ in some zooecia; in mature zone diaphragms usually spaced from somewhat less than one-half to $1 \frac{1}{2}$ zooecial diameters apart; diaphragm spacing gradually diminishes from center of axis to base of mature zone. Mesopores and acanthopores absent.

Remarks. - Monotrypella normalis is represented in the Spechts Ferry collections by two specimens, each from a different locality, from which three tangential and two longitudinal sections, as well as one transverse section, were prepared. The paratype is a fragment from near the distal extremity of the zoarium, 
displays a poorly developed mature zone, and has somewhat more abundant diaphragms in the axial region than the holotype. Zooecial apertures in the tangential section of the paratype are somewhat elongate as the zooecia are inclined slightly to the zoarial surface.

The three tangential sections commonly show angular or subround cells that are smaller than normal zooecia and consequently simulate mesopores. Longitudinal and transverse sections, however, do not reveal small closely tabulate or moniliform tubes, and thus the writer concludes that mesopores are absent. Ulrich and Bassler (1904, p. 44) suggest that Monotrypella is a rare and probably unique genus, although Bassler (1953, p. Gl09) still recognizes its validity at a much later date. Structural characteristics of the specimens under study, however, dictate their assignment to Monotrypella. The specific name has been selected to indicate that this species has all the structural characteristics of its genus.

The closest relative to Monotrypella normalis is the type species of the genus, $M$. aequalis Ulrich, from the Eden (early Cincinnatian), which differs from $M$. normalis in having larger zooecia and in virtually lacking diaphragms in the axis.

Distribution. - Localities 6, 10.

Types. - Illinois State Geological Survey; holotype 12P68, paratype 12P216.

Family TREMATOPORIDAE Miller, 1889

Genus BATOSTOMA Ulrich, 1882

Type species: Batostoma implicatum (Nicholson)

BATOSTOMA WINCHELLI SPINULOSUM Ulrich

Plate 5, figures $4-6$

Batostoma winchelli var. spinulosum Ulrich, 1895, Geol. Minnesota, v. 3, pt. 1, p. 296, pl. 27, figs. 7, 8; Zittel, 1896,

Textbook of Paleont. (Eng. edit.), p. 275, fig. 459C;

Bassler, 1911, U. S. Nat. Mus. Bull. 77, p. 279, figs. 167, 168; Fritz, 1957, Geol. Survey Canada Bull. 42, p. 12, pl. III,

figs. 1,2 .

External features. - Zoarium ramose, the incomplete specimen $29 \mathrm{~mm}$ long and $7 \mathrm{~mm}$ in diameter. Acanthopores clearly visible, mainly at junction angles of adjoining zooecia, as dark, slightly protuberant spines. Maculae not common, irregularly distributed, flush with surface, and composed of about four to seven zooecia above average in size and two or three associated mesopores.

Tangential section. - Zooecia subangular and generally having broadly ovate or somewhat irregularly shaped apertures that are commonly inflected by prominent acanthopores; most commonly (seven of ten measurements) six entire zooecia and part of seventh in $2 \mathrm{~mm}$, measuring parallel to length of zoarium; less commonly (two of ten measurements) five complete zooecia and portion of sixth or (one of ten measurements) seven entire zooecia and part of eighth in this distance; average maximum apertural diameter of zooecia, exclusive of zooecial walls, 0.26 $\mathrm{mm}$, ranging from 0.23 to $0.28 \mathrm{~mm}$ for ten measurements. Acanthopores abundant, generally four to six associated with each zooecium, occupying most junction angles of adjoining zooecia and also in zooecial walls between junction angles, usually ranging in diameter from 0.04 to $0.07 \mathrm{~mm}$, and commonly inflecting zooecial apertures strongly. Mesopores moderately common. Cluster of about four zooecia above average in size and associated mesopores represent a macula. 
Longitudinal section. - Zooecia erect, thin-walled in axis, bending gradually to meet zoarial surface, the curvature increasing somewhat at base of mature zone where diaphragm spacing markedly diminishes and zooecial wall thickness increases. Diaphragms in axis usually spaced from somewhat over one to about five zooecial diameters apart and in mature region generally spaced from slightly less than one-half to nearly one zooecial diameter apart. Mesopores closely tabulate and not observed below base of mature zone. Acanthopores locally conspicuous in mature zone but generally observed only in a short segment of zooecial wall.

Remarks. - The Spechts Ferry collection includes only one specimen of this distinctive form from which two longitudinal and two tangential sections were prepared. Unfortunately, the specimen has undergone silicification to a considerable depth within the mature region; this form of preservation has largely obliterated details of wall structure, but locally and obscurely the walls appear integrate in tangential section.

Distribution. - Locality 9.

Type. - Hypotype, Illinois State Geological Survey, 12P219.

\section{BATOSTOMA WINCHELLI (Ulrich)}

Plate 6, figures 4-11

Amplexopora winchelli Ulrich, 1886, 14th Ann. Rept., Geol. Nat. Hist. Survey Minnesota, p. 91 .

Batostoma winchell Ulrich, 1895, Geol. Minnesota, v. 3, p. 295, pl. 26, figs. 33, 34, 36, 37, pl. 27, figs. 1-6; Bassler, 1911, U. S. Nat. Mus. Bull. 77, p. 278, 279, fig. 166; Wilson \& Mather, 1916, Ontario Bur. Mines, v. 25, pt. 3, p. 49, 55; Wilson, 1921, Geol. Survey Canada Bull. 33, Geol. Ser. 40, p1. II, figs. 7, 8; Loeblich, 1942, Jour. Paleontology, v. 16, no. 4, p. 432, pl. 64, figs. 8-10; Wilson, 1949, Tennessee Div. Geol. Bull. 56, pl. 13, fig. 11; Fritz, 1957, Geol. Survey Canada Bull. 42, pl. IV, figs. 1-3.

External features. - Zoarium ramose, the fragments ranging in length from 10 to $31 \mathrm{~mm}$ and in width from 3.5 to $9 \mathrm{~mm}$ and commonly showing one bifurcation. Zooecia thick-walled, angular to subangular; acanthopores locally abundant, particularly where zooecial walls are somewhat thinner. Zoarial surface smooth and showing sparse irregularly distributed maculae composed of several zooecia above average in size or of large and small tubes.

Tangential section. - Zooecia angular to subangular and usually having broadly ovate or subangular apertures; most commonly seven entire zooecia and part of eighth in $2 \mathrm{~mm}$, measuring parallel to length of zoarium. Zooecial walls most commonly integrate but locally amalgamate, the wall thickness ranging from 0.02 to $0.16 \mathrm{~mm}$ but usually from 0.04 to $0.06 \mathrm{~mm}$. Acanthopores generally at junction points of adjoining zooecia, usually small but commonly of medium size, rarely inflecting and, where abundant, two to six, typically three or four, acanthopores associated with each zooecium; where sparse, two to four occurring with ten zooecia; many acanthopores lacking hollow centers and composed of concentrically arranged black fibers. Mesopores absent or, when rare, small. Maculae composed of six to eight zooecia about one-quarter larger than those of intermacular areas or of large and small tubes.

Longitudinal section. - Zooecia erect in axis, bending gradually to intersect zoarial surface at right angles. Diaphragms in axis usually one to eight, 
most commonly two to five, zooecial diameters apart but in mature zone generally spaced one-half zooecial diameter or less apart. Diaphragms in mature zone commonly arched, convex outward, and uniting with adjacent proximal diaphragm . Zooecial walls thin, straight or mildly flexuous in axis and perceptibly thickening near base of mature zone. Zooecial walls in mature region generally integrate, consisting of acute $\wedge$-shaped laminae and containing a centrally located mildly undulatory black divisional line passing through the apices of the laminae; less commonly, walls obscurely integrate or amalgamate and composed of laminae more broadly convex outward. Zooecial wall material continuous into diaphragms, particularly in zooecia having distinctly integrate walls. Closely tabulate tubes, below average in size and confined to mature zone, rare and interpreted as mesopores. Remarks. - This species is represented in the Spechts Ferry collections by twenty-two sectioned specimens.

Batostoma winchelli shows considerable variation in structure, particularly in tangential sections. Acanthopores vary in abundance not only from specimen to specimen but, in a more striking manner, within the same zoarium. In some specime.ss, however, acanthopores are uniformly abundant throughout the section. In other specimens acanthopores are abundant (three to five with each zooecium) in part of the section but are comparatively rare (one to three as sociated with ten zooecia) elsewhere in the section. Further, acanthopores vary considerably in prominence; a few of the Spechts Ferry specimens have acanthopores comparable in size to those figured by Ulrich $(1895, \mathrm{pl} .27$, figs. 4,6$)$ but in most specimens

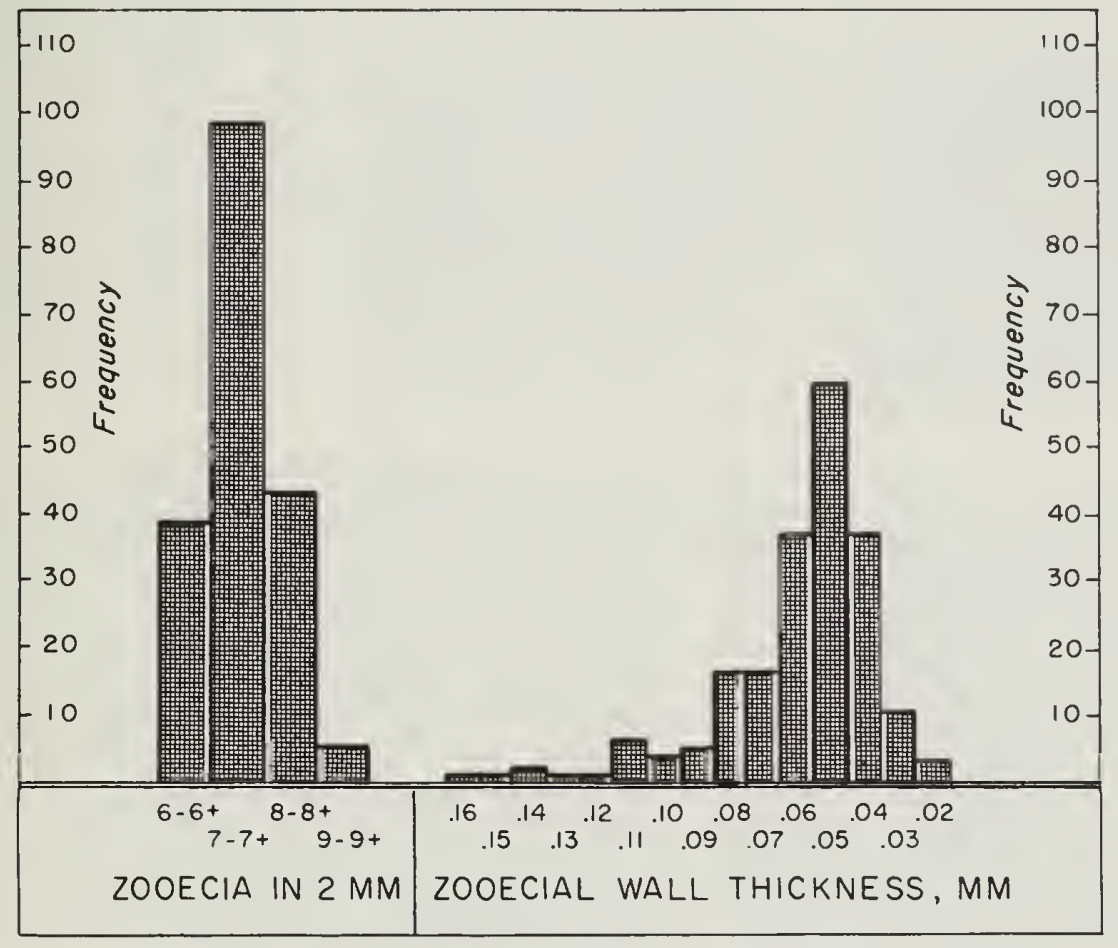

Text fig. 3 - Measurements on Batostoma winchelli (Ulrich). $6+$ signifies six entire zooecia and part of seventh in a $2-\mathrm{mm}$ distance. 
these structures are somewhat smaller, suggestive of Bromide forms (Loeblich, 1942, pl. 64, fig. 8). In addition to structural variation shown by the acanthopores, the nature of the zooecial wall shows considerable variation in tangential section. Although some specimens show clearly integrate walls throughout their section, others may display integrate and amalgamate walls in the same section. Finally, angular or subangular tubes, generally from about one-quarter to somewhat over one-half the size of a typical zooecium, are interpreted as small zooecia rather than mesopores. The paucity of closely tabulate tubes of small size in longitudinal sections suggests that mesopores are rare.

In longitudinal section, this species displays more structural stability, although considerable variation in the spacing of the diaphragms in the axis is observed; diaphragms are virtually lacking in the axial region of a very few zooecia. The Spechts Ferry specimens differ somewhat from conspecific forms described both by Ulrich (1895, p. 296) and Loeblich (1942, p. 433) who report that the maximum spacing between successive diaphragms in the axial region is three and four zooecial diameters, respectively. Erection of a new species on this structural difference is certainly not justified. Longitudinal sections show under high magnification ( $\times 210)$ that locally and somewhat rarely a cingulum may be developed. Where a cingulum is observed, the material of these secondary deposits (Cumings and Galloway, 1915, p. 361) is continuous into the diaphragms. Finally, longitudinal sections show that the distal extremities of a few zooecia are filled with a dense calcareous deposit that has largely obliterated the diaphragms.

Text figure 3 shows the variation in number of zooecia in $2 \mathrm{~mm}$, measuring parallel to the length of the zoarium, and in zooecial wall thickness as observed in tangential section.

Distribution. - Localities 1, 2, 4, 5, 6, 7, 8, 10.

Types, - Hypotypes, Illinois State Geological Survey, 12P4, 12P12, 12P25, $12 \mathrm{P} 44,12 \mathrm{P} 46,12 \mathrm{P} 47,12 \mathrm{P} 67,12 \mathrm{P} 83,12 \mathrm{P} 89,12 \mathrm{P} 90,12 \mathrm{P} 132,12 \mathrm{P} 136,12 \mathrm{P} 139$, 12P143, 12P149, 12P156, 12P190, 12P191, 12P195, 12P198, 12P206, $12 \mathrm{P} 218$.

\section{EXPLANATION OF PLATE 7}

Figure 1 is $\mathrm{X} 4$; figures $2-4$ and 6 are X60; all others are X20.

Specimen number and collecting locality are shown in parentheses following explanation of each figure; for example, (12P77, 4) refers to specimen 12 P77 obtained from collecting locality 4. Structures in photographs are not retouched.

\section{Figure}

$1-9$

Stictoporella frondifera Ulrich. 1. Surface of zoarium showing maculae $(12 \mathrm{P} 77,4) .2$. Tangential section showing zooecial wall structure $(12 \mathrm{P} 101,6)$. 3. Longitudinal section showing zooecial wall structure and mesotheca near base of illustration (12P184, 8). 4. Tangential section from same specimen as figure 2 showing cingulumlike structures $(12 \mathrm{P} 101,6)$. 5. Tangential section (12P240,6). 6 . Tangential section showing prominent development of centrally located dark-colored divisional line between zooecial apertures $(12$ P77, 4). 7. Tangential section from same specimen as figure 5 . Note variation in mesopore abundance in this specimen $(12 \mathrm{P} 240,6)$. 8. Longitudinal section showing bifoliate nature of zoarium (12P184, 8). 9. Tangential section $(12 \mathrm{P} 184,8)$. 

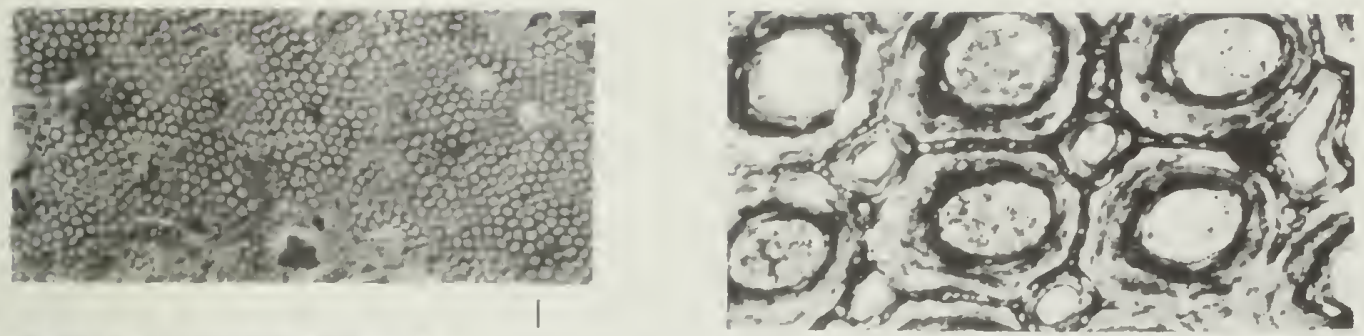

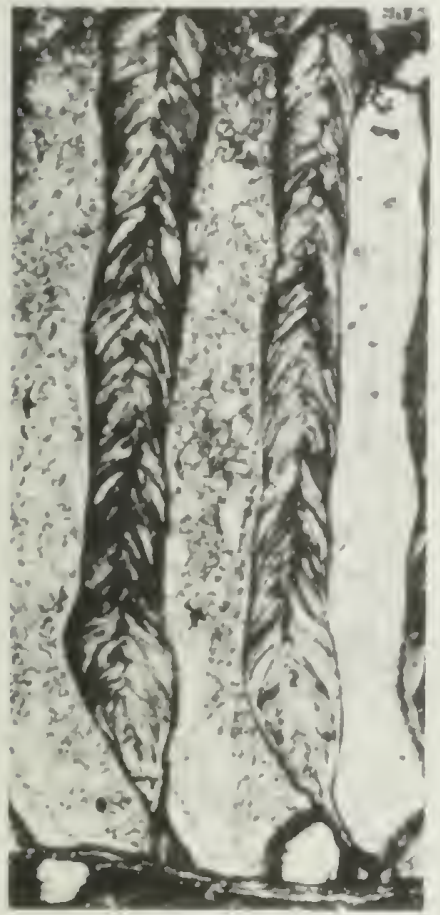

3
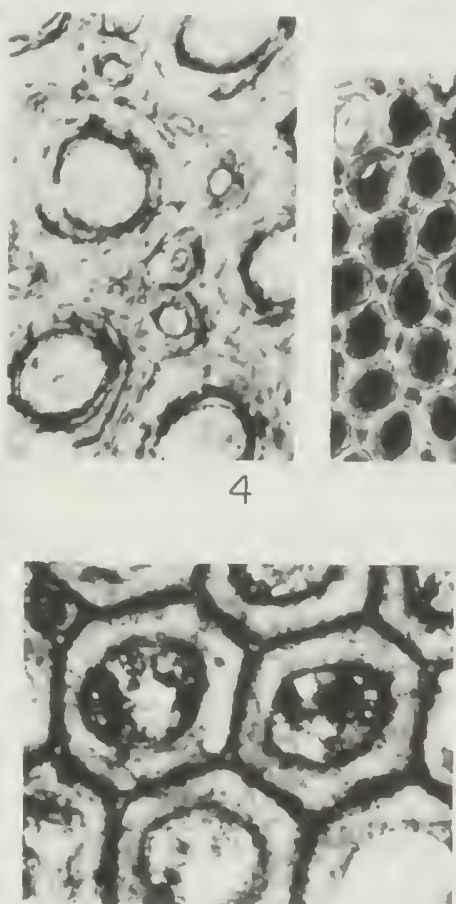

6

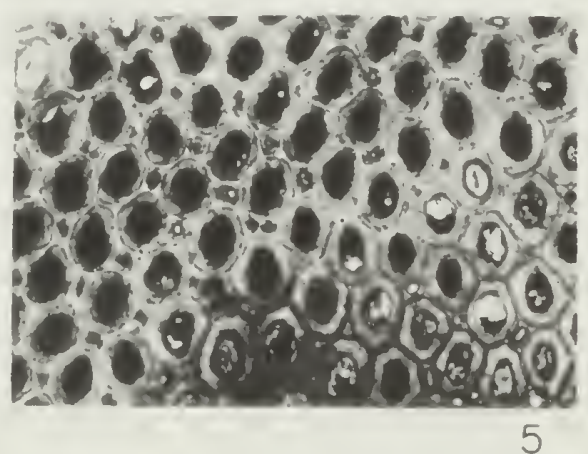

5

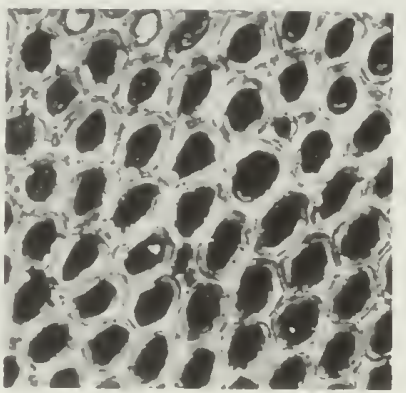

7

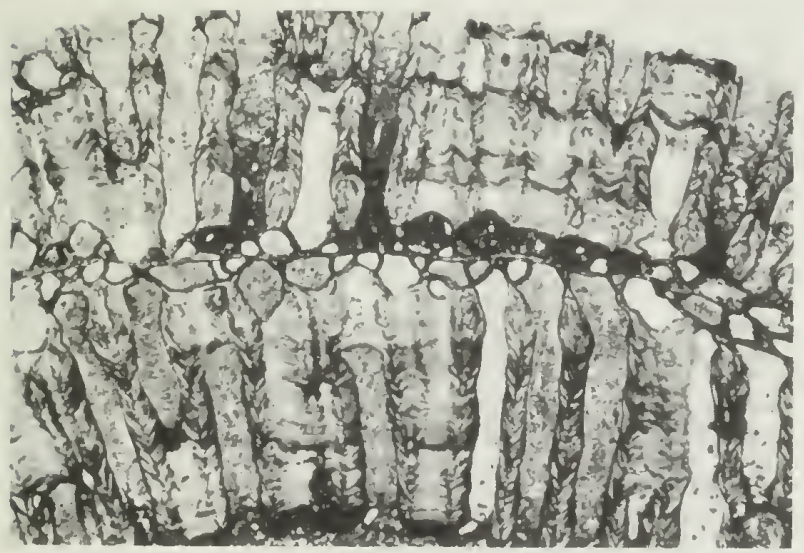

Iद (1) 3 . $\frac{1}{6}(8)$

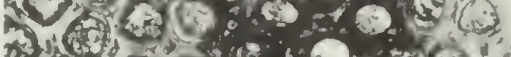

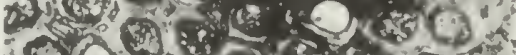
1.0 $=1$ G \% \& हों 10 . 10 .

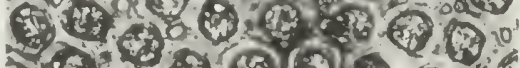
Dise 4 (B) 3 ? (i.)

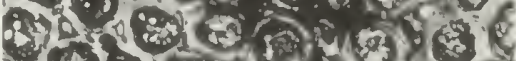

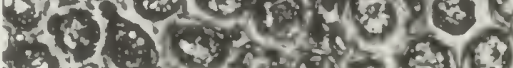



Genus DIPLOTRYPA Nicholson, 1879

Type species: Diplotrypa petropolitanus (Pander)

DIPLOTRYPA sp.

Plate 5, figures 7,8

External features. - Zoarium a nearly circular sheetlike growth, $9.5 \mathrm{~mm}$ in diameter and slightly less than $2.0 \mathrm{~mm}$ thick, attached to a brachiopod valve. Cluster of four zooecia slightly above average in size may represent macula.

Tangential section. - Zooecia nearly circular or broadly ovate and having walls of moderate thickness (about $0.02 \mathrm{~mm}$ or slightly less) composed of fine laminae parallel to apertural periphery; most commonly (seven of 12 measurements) six entire zooecia and part of seventh in $2 \mathrm{~mm}$; less commonly (five of 12 measurements) five entire zooecia and portion of sixth in this distance; average maximum apertural diameter of zooecia, not including zooecial walls, $0.30 \mathrm{~mm}$, ranging from 0.27 to $0.35 \mathrm{~mm}$ for 16 measurements. Adjacent zooecia locally in contact but partially separated by mesopores. Cluster of four zooecia somewhat above average in size represents macula. Acanthopores not observed.

Longitudinal section. - Zooecia erect, of nearly uniform wall thickness throughout length, and usually containing five or fewer diaphragms per zoecium; diaphragms mainly localized in lower half of zoarium. Mesopores abundant, closely tabulate.

Remarks. - This genus is represented in the collections by a single rather poorly preserved specimen from which one longitudinal and two tangential sections were obtained. Because of the small size of the sections and unfavorable preservation, the specimen could not be compared adequately with previously described species of the genus.

Distribution. - Locality 10.

Described specimen. - Illinois State Geological Survey, 12P207.

Order CRYPTOSTOMATA Vine, 1883

Family STICTOPORELLIDAE Nickles \& Bassler, 1900

Genus STICTOPORELIA Ulrich, 1882

Type species: Stictoporella interstincta Ulrich

STICTOPORELLA FRONDIFERA Ulrich

Plate 7 , figures $1-9$

Stictoporella frondifera Ulrich, 1886, 14th Ann. Rept., Geol. Nat. Hist. Survey Minnesota, p. 72; Ulrich, 1895, Geol. Minnesota, v. 3, p. 183, pl. XI, figs. 12-19.

External features. - Zoarium a bifoliate leaflike or palmate expansion, the largest incomplete specimen $45 \mathrm{~mm}$ long and $37 \mathrm{~mm}$ wide, generally less than $2 \mathrm{~mm}$ thick, and commonly showing flat lobes or compressed incipient branches extending from the main zoarial mass. Zooecial apertures broadly ovate to polygonal and surrounded by thick walls. Maculae sporadically distributed but commonly 3 to $4.5 \mathrm{~mm}$ apart, measuring from center to center, and usually composed of approximately eight to twenty mesopores; elsewhere, mesopores rare to common.

Tangential section. - Zooecia angular, thick-walled, and having broadly ovate to subcircular apertures; most commonly (212 of 382 measurements on 39 


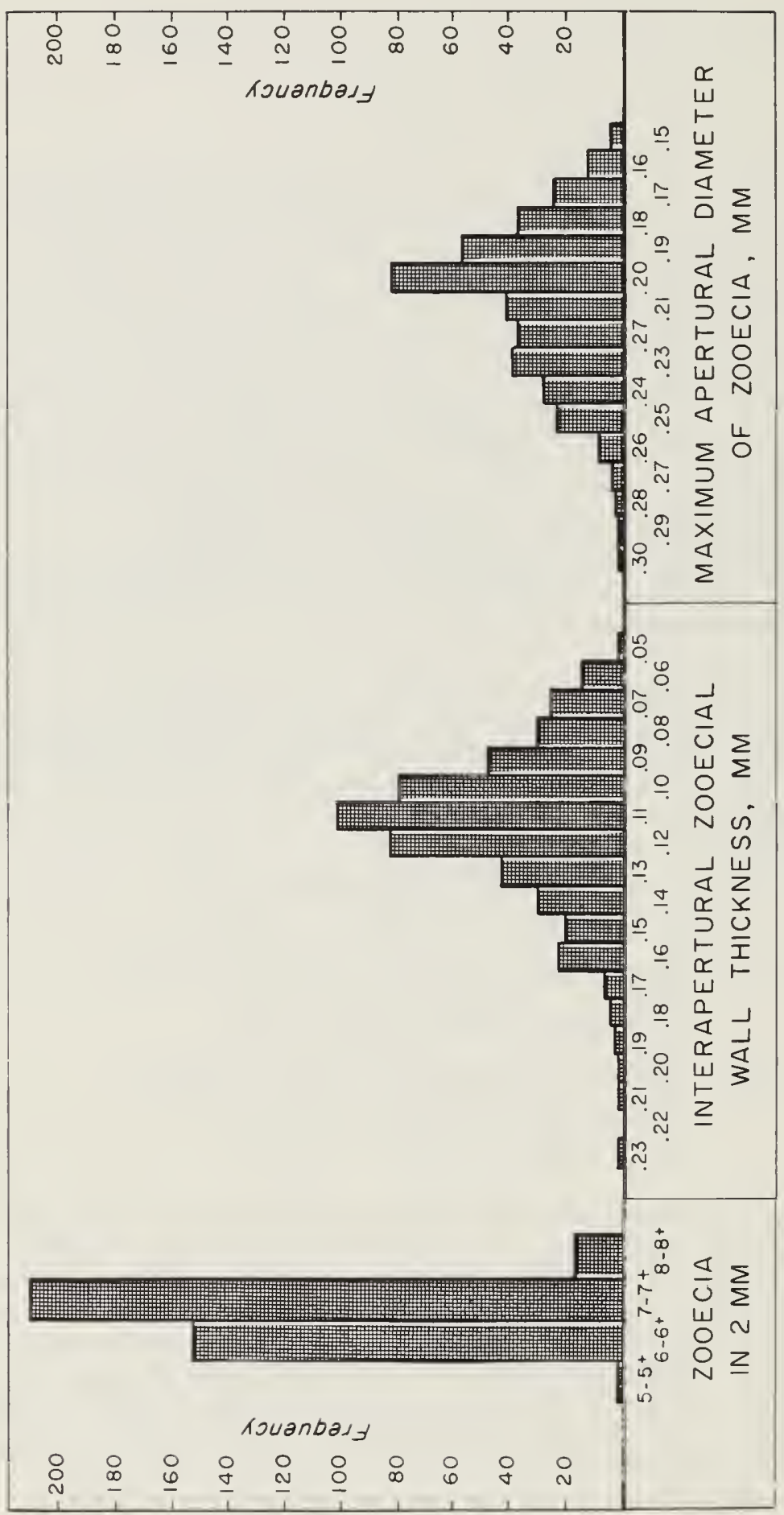

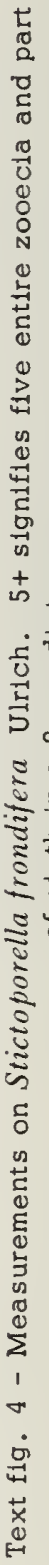


specimens) seven entire zooecia, or seven complete zooecia and part of eighth, in $2 \mathrm{~mm}$, measuring as closely as possible parallel to direction of elongation of zooecial apertures; less commonly (154 of 382 measurements on 39 specimens) six complete zooecia or six entire zooecia and part of seventh in this distance; maximum diameter of zooecial aperture averages $0.21 \mathrm{~mm}$ (404 measurements on 39 specimens); average interapertural zooecial wall thickness (522 measurements on 39 specimens) is $0.11 \mathrm{~mm}$; zooecial wall material commonly consisting of fine laminae concentrically disposed about zooecial apertures; divisional line between adjoining zooecia commonly prominent, dark- or light-colored, but in some specimens locally obscure; cingulum-like structures associated with many zooecial apertures. Mesopores thick-walled, angular or subangular, generally with round or ovate apertures that commonly are strikingly smaller than mesopores because of thickness of mesopore wall material; mesopores aggregated into maculae, elsewhere sparse to common; in some specimens, mesopores common in some areas but virtually absent elsewhere.

Longitudinal section. - Mesotheca thin, somewhat flexuous, and apparently lacking tubuli or foramina. Zooecia usually somewhat prostrate and thin-walled in earliest development but rapidly becoming erect and very thick-walled; zooecial wall material of conspicuously developed $\wedge$-shaped laminae; divisional line between contiguous zooecia commonly observed. Diaphragms lacking .

Remarks. - From 404 measurements on 39 specimens, the maximum apertural diameter of the zooecia, exclusive of the zooecial walls, averages $0.21 \mathrm{~mm}$. The average for different specimens does not deviate from $0.21 \mathrm{~mm}$ by more than 0.04 $\mathrm{mm}$; and this for only one specimen on which ten apertures were measured. The average interapertural zooecial wall thickness, based on 522 measurements on 39 specimens, is $0.11 \mathrm{~mm}$. For any particular specimen, the average value of this dimension is not greater than 0.15 or less than $0.08 \mathrm{~mm}$. Text figure 4 shows measurements of maximum apertural diameter of the zooecia, interapertural zooecial wall thickness, and number of zooecia in $2 \mathrm{~mm}$.

Spechts Ferry representatives of this species show considerable variation in number of mesopores. Such variation is displayed not only from specimen to specimen but also within different areas of the same zoarium. Mesopores are so scarce in some parts of the colony that locally a marked similarity is shown in tangential section to Stictoporella angularis Ulrich, a species characterized by its paucity of mesopores (Ulrich, 1895, pl. XI, fig. 8) and ribbonlike branches that are 1.5 to $3.0 \mathrm{~mm}$ wide; el sewhere, in the same zoarium, mesopores are considerably more plentiful as in S.frondifera (Ulrich, 1895, pl. XI, fig. 16). None of the Spechts Ferry specimens identified as $S$.frondifera approach $S$. angularis in zoarial form, but some have noticeably fewer mesopores than in $S$. frondifera as figured by Ulrich; some may recommend assignment of these latter specimens to $S$. angularis var. intermedia, which Ulrich (1895, p. 183) regarded as occupying an intermediate position between $S$. angularis and $S$. frondifera. The writer feels that $S$. angularis, $S$. angularis var. intermedia, and $S$. frondifera possibly may have been members of a single natural population.

The divisional line between adjoining zooecia may be observed throughout the entire tangential section of some specimens, as is depicted by Ulrich (1895, pl. XI, fig. 16), but in other specimens this line is prominent locally although obscure or not observed in other areas. I felt that the prominence of development of this divisional line may be related to depth of sectioning; tangential sections, however, prepared at different levels or depths within the zoarium, indicated such is not the case. 
Distribution. - All localities, except 3.

Types. - Hypotypes, Illinois State Geological Survey, 12P19, 12P50, 12P53, $12 \mathrm{P} 57,12 \mathrm{P} 60,12 \mathrm{P} 62,12 \mathrm{P} 63,12 \mathrm{P} 76,12 \mathrm{P} 77,12 \mathrm{P} 78,12 \mathrm{P} 79,12 \mathrm{P} 80,12 \mathrm{P} 81,12 \mathrm{P} 82$, $12 \mathrm{P} 84,12 \mathrm{P} 85,12 \mathrm{P} 86,12 \mathrm{P} 98,12 \mathrm{P} 99,12 \mathrm{P} 100,12 \mathrm{P} 101,12 \mathrm{Pl} 12.12 \mathrm{Pl} 13,12 \mathrm{Pl} 14$, $12 \mathrm{Pl} 15,12 \mathrm{Pl} 16,12 \mathrm{P} 181,12 \mathrm{Pl} 82,12 \mathrm{Pl} 44,12 \mathrm{Pl} 87,12 \mathrm{P} 200,12 \mathrm{P} 201,12 \mathrm{P} 203$, 12P209, 12P212, 12P221, 12P225, 12P236, 12P237, 12P238, 12P239, 12P240.

\section{REFERENCES}

Agnew, A. F., Heyl, A. V., Jr., Behre, C. H., Jr., Lyons, E. J., 1956, Stratigraphy of middle Ordovician rocks in the zinc-lead district of Wisconsin, Illinois, and Iowa: U. S. Geol. Survey Prof. Paper 274-K, P. 251-334.

Bassler, R. S., 1903, The structural features of the bryozoan genus Homotrypa, with descriptions of species from the Cincinnatian Group: U. S. Nat. Mus. Proc., v. 26, no. 1323, p. 565-591, pls. 20-25.

Bassler, R. S., 1911, The early Paleozoic Bryozoa of the Baltic provinces: U.S. Nat. Mus. Bull. 77, 382 p., 13 pls.

Bassler, R. S., 1932, The stratigraphy of the Central Basin of Tennessee: Tennessee Div. Geol. Bull. 38, 268 p., 49 pls.

Bassler, R. S., 1933, Development of invertebrate paleontology in America: Geol. Soc. America Bull., v. 44, pt. 2, p. 265-286.

Bassler, R. S., 1953, Bryozoa, Pt. G, Treatise on invertebrate paleontology [R. C. Moore, ed.]: Geol. Soc. America and Univ. Kansas Press, Lawrence, Kansas, $253 \mathrm{p}$.

Bays, C. A., and Raasch, G. O., 1935, Mohawkian relations in Wisconsin: Kansas Geol. Soc. 9th Ann. Field Conf. Guidebook, p. 296-301.

Caley, J. F., 1936, The Ordovician of Manitoulin Island, Ontario: Geol. Survey Canada Mem. 202, pt. 2, p. 21-90, 6 pls.

Coryell, H. N., 1916, A study of the collections from the Trenton and Black River Formations of New York: Indiana Acad. Sci. Proc., v. 31, p. 249-268.

Coryell, H. N., 1921, Bryozoan faunas of the Stones River Group of central Tennessee: Indiana Acad. Sci. Proc., v. 35, p. 26l-340, 14 pls.

Cumings, E. R., and Galloway, J. J., 1912, The stratigraphy and paleontology of the Tanner's Creek section of the Cincinnati Series of Indiana: Indiana Dept. Geol. Nat. Resources 37th Ann. Rept., p. 353-478, 20 pls.

Cumings, E. R., and Galloway, J. J., 1915, Studies of the morphology and histology of the Trepostomata or monticuliporoids: Geol. Soc. America Bull., v. 26, p. 349-374, pls. 10-15. 
Fritz, M. A., 1957, Bryozoa (mainly Trepostomata) from the Ottawa Formation (middle Ordovician) of the Ottawa-St. Lawrence Lowland: Geol. Survey Canada Bull. 42, 75 p., 30 pls.

Herbert, Paul, Jr., 1949, Stratigraphy of the Decorah Formation in western Illinois: Univ. Chicago Ph.D. thesis and Illinois Geol. Survey unpublished manuscript .

Horowitz, A. S., and Perry, T. G., 1956, Fauna of the Glen Dean Limestone (middle Chester) of Indiana and northern Kentucky (abstract): Geol. Soc. America Bull., v. 67, p. 1707-1708.

Kay, G. M., 1928, Divisions of the Decorah Formation [in northeastern Iowa]: Science, new ser., v. 67, p. 16 .

Kay, G. M., 1929, Stratigraphy of the Decorah Formation: Jour. Geol., v. 37, p. 639-671.

Kay, G. M., 1931, Stratigraphy of the Ordovician Hounsfield metabentonite: Jour . Geol., v. 39, p. 361-376.

Kay, G. M., 1934, Mohawkian Ostracoda: Species common to Trenton faunules from the Hull and Decorah Formations: Jour. Paleontology, v. 8, no. 3, p. $328-343, \mathrm{pls} .44-46$.

Kay, G. M., 1935, Ordovician System in the upper Mississippi Valley: Kansas Geol. Soc. 9th Ann. Field Conf. Guidebook, p. 281-295.

Kay, G. M., 1940, Ordovician Mohawkian Ostracoda: Lower Trenton Decorah fauna: Jour. Paleontology, v. 14, no. 3, p. 234-269, pls. 29-34.

Kay, G. M., and Atwater, G. I., 1935, Basal relations of the Galena Dolomite in the upper Mississippi Valley lead and zinc district: Am. Jour. Sci., v. 29, 5th ser., p. 98-111.

Loeblich, A. R., Jr., 1942, Bryozoa from the Ordovician Bromide Formation, Oklahoma: Jour. Paleontology, v. 16, no. 4, p. 4l3-436, pls. 6l-64.

Nicholson, H. A., 1879, Paleozoic tabulate corals: 342 p., 15 pls., William Blackwood and Sons, Edinburgh and London.

Sproule, J. C., 1936, A study of the Coburg Formation: Geol. Survey Canada Mem. 202, pt. 3, p. 93-119, 3 pls.

Templeton, J. S., and Willman, H. B., 1952, Guidebook for the 16th Tri-State Geol. Soc. Ann. Field Conf., Illinois Geol. Survey, 47 p.

Troedsson, G. T., 1928, On the middle and upper Ordovician faunas of northern Greenland, Pt. II: Meddelser om Gronland, v. 72, pt. I, 197 p., 56 pls.

Twenhofel, W. H., et al., 1954, Correlation of the Ordovician formations of North America: Geol. Soc. America Bull., v. 65, p. 247-298.

Ulrich, E. O., 1886, Report on the lower Silurian Bryozoa with preliminary descriptions of some of the new species: Minnesota Geol. and Nat. Hist. Survey 14th Ann. Rept., p. 55-103.

Ulrich, E. O., 1895, On the lower Silurian Bryozoa of Minnesota: Minnesota Geol. and Nat. Hist. Survey, v. 3, pt. 1, p. 96-332, 28 pls. 
Ulrich, E. O., and Bassler, R. S., 1904, A revision of the Paleozoic Bryozoa. Pt. II-Trepostomata: Smith. Misc. Coll., v. 47, no. 1470, p. 15-55, pls. 6-14.

Weiss, M. P., 1957, Upper middle Ordovician stratigraphy of Fillmore County, Minnesota: Geol. Soc. America Bull., v. 68, p. 1027-1062, 5 pls.

Wilson, A. E., 1921, The range of certain lower Ordovician faunas of the Ottawa Valley with descriptions of some new species: Geol. Survey Canada Bull. 33, Geol. Ser. 40, p. 19-57, 4 pls.

Wilson, A. E., and Mather, K. F., 1916, Synopsis of the common fossils of the Kingston area, in Baker, M. B., The geology of Kingston and vicinity: Ontario Bur. Mines, v. 25, pt. 3, p. 45-66, 3 pls.

Wilson, C. W., Jr., 1949, Pre-Chattanooga stratigraphy in central Tennessee: Tennessee Div. Geol. Bull. 56, 407 p., 28 pls.

Illinois State Geological Survey Circular 326

36 p., 4 text figs., 7 pls., 1962 

CIRCULAR 326

ILLINOIS STATE GEOLOGICAL SURVEY URBANA 